

\section{SILFCULTURE DIRECTORY}

4ND

I

SILK-GATERPILLARS DISORDERS,

BY

6. BARRICEELE.

(11th Edition, the 3d in English.)

*Ex Cathedra.*

1884. 
Gathering the Silk (rop.

Preserving the Cocoon

Selling and Shiphoug

Seventh Age.

Butterflies, Fecundation, Eggs.

Preservation of Sron!

Conclusion

Aiveratix

Tahte.

Plistish.

$$
\text { SE(O) TH PAT (Diseases). }
$$

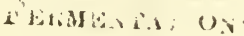

INCLHAHLE

$\left\{\begin{array}{l}\text { Bursting } \\ \text { Deouy } \\ \text { Cimmene }\end{array}\right.$

AIOIDS:LE

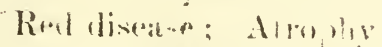

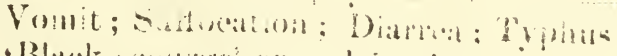

- Blatek acoutere or elal ination:

Dorpley: damblice

A-plyixy: totian

Buitertlins: Discases:

Comollaty

Generwition

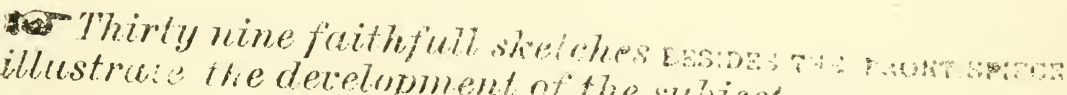
ibustru: the development of the sulyest. 


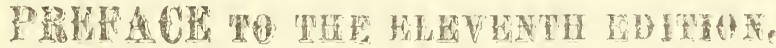

the lst in English.)

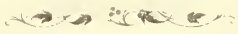

The water indutry for hosewives, girls, shool girls, thrifty ladies women in genoul, semy-invalid people, boys out of sehool, smart children, tramere in vacation, people enjoying the country,

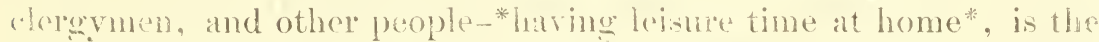
BRT OF GROWING SILK.

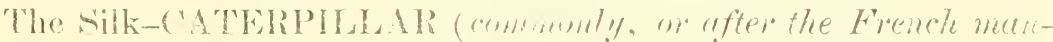

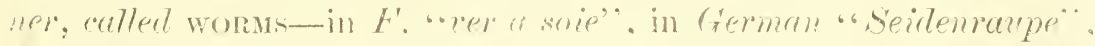
in Tratian "brifutto" "de.) that produce their highly priced textil material, so much sought after hy dimitaries and by brides, is se (LAAX AND INDUATRIOUS THAT IT RIMLS THE BEE, AXD GO MARM-

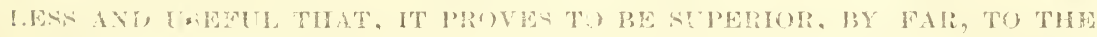

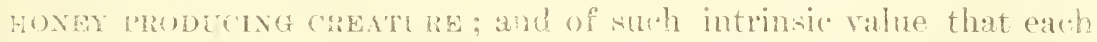
10.000 of them (ocenpying no mone than fifteen square vards of surface yield mose dollats and (ronts, in 10 days, than ten hear is the lapse of a rear, for":

l'en thousand silk-f aterpillares, of selected breed and in favourable season, will moluce. in arout forty duys, silk valued at, abont, twelee dollaws, whilut tea hans can searcely produce 200 egos, in surh lenght of time, havdy valued two dollurs and no more :

We cirote the hens becalse, usualiy, they are the noms muloved to mase nin money; but it is lot difficult to plove that even a cow produres, in firty days less then at brood' of silk-('aterpillars. In fact if a cor iche, in same time, 120 gallons of milk it brings intu 
the house less than six dollars, (not either caleulating the cutlar uvested for her keeping) when if, say, 20,000 of (aterpillars at"* reared, with little trouble, small expense and in such short time. bey can give over twenty dollars of profit. But*it must be hinted 3. new, that the gains on silk-arowing can be obtained without gising up other industries, without buying fodder. without renting any expensive buildingr--as stables etc. •and at home”*

Silk, mostly used by ladies, clergynen and secular dignitaries. is arised, (for pastime, in the Old World) practically hy the same "onsumers and other refined and intelligent persons. Then altho igh it is true that peasants grow silk there. yet they do it direeted b? arned leaders who take care of the silk--Caterpillar's egrg in winter and spring and, then, hatch them with artificial healthful contrivances. So it is a matter of fact (when such fine peraons attrond to this industry) that no hard work is needed to secure a silk-crop and that it affords "good retures ron bined with kichlecige of Natural History as well as anusc ment.

Those who grow silk in the Old World are provided with famity help, mulberry--trees and room: but those who will grow it here should have airy room. osaGe p!ant:- vice mulbery-trees, and famIy assistance--hired labor not being profitable for silk "row?

Thence people who find their home-life weary-for need of any oceupation and are losing the profits of exercie, pracical study of Entomology and mighty dollars, enuld undertake to rear here thore dear little pets which produce the precious material. with which are woven those valuable silk-goods, su indispensable w brides.

In Italy, China, Xapan and Persia Silk--(ulture is Pnc.umard and protected: it being the industry of the people. at latror, and a! the same time one of the sources for the revenues of said countries. it is guided and joirected by their governmentis. It is $x \cdot ! l \mathrm{knn}, \mathrm{wn}$. 


\section{$\because R \because A B C B$.}

noif-a-cha, how the Fumpess of ( hina presides, in that vast empire, wre this most raluhbl produce, and how, early in spring, she anbounces to her subjects to prepare themselves for the approaching seanon of 'ares'; it is sko well known how on the 14 of January "ach year, in Iapan is colemnly performed the rie of "washing, cxamining and reanoiner (whilst they fast, pray, and sacrifice to their. (rods) the egress of the Silk-( crtexpillar. But, perhaps, it in not yet known that. in Italy 12 ycars ago (1871) the government ogrened a Silk-Culture Dircetoy in cach province of the State and that by the scientific employees of said Directories (right under the vigilance of the Minister of Agriculture) the great Italian silk("op) are grenerally managed.

Now if the wealth so cagerly sought for by other people and gov"muneus, the "silk wealth" which enabled France to raise suddent's" from the disasters of 1870 . is not entitled to be protected and encouraged here also, then we may just think that we are not livings, in this time of progress in which * 352 silk-mils are manufacturiags imported raw-silk, but in the time of "ti) years ago", when silk was grown here, but had no sale.*

St. Louis, February $26.188 \%$. 


$$
\begin{gathered}
\text { P'BLINHEI; } \\
\text { by (the) }
\end{gathered}
$$

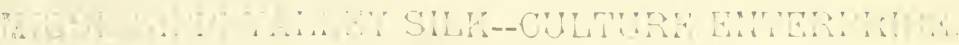
$\because$ inen, $\cdots$.

$\underbrace{2}$ 


\section{FIRST PART.}

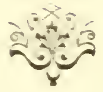

\section{HOW TU PEA}

SLAEABARILLARS.

$$
\text { … ‥ }
$$





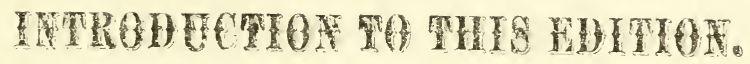

-ovison

The tirst American edition (5000) of this Directory was exahusted before its number could be distributed to all the pereons who applie d for a copy. The foremost merits of surh an exceptional demand [for a book on an almost new topic] were not alone its vory abes: directions in rearing silk-Caterpillars, (becanse, although there is no silk-Culture here, in the real meaning of the term, yet here c $\because$ a be had, at least, a dozen of pamplilets on the subject) but aline if:

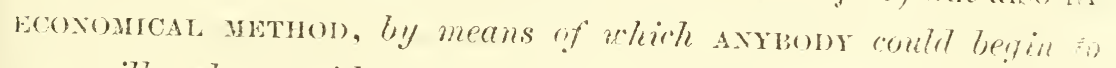
grou" sille, almost without expenses-i.e. neither ureding an!l conital (o) start with, nor running any risk of a loss.

Having griven the abore explanation it is deemed, now, a matts of the atmost importance, to inform the "iroukd be silk-grower's? abont the following important inquiries.

\section{Mgill is pay?}

In iruth : to grow silk, it is many times more dificult than to laiso crain, coln, cattle, or proultry: but it must be remembered that, a ! the farm produces are as much liabie to fail (by dromght food, ir sects, epizotic ete.) as are the (aterpillars exposed to failure by amosferie inflances, although the former are so in lesser dergees. Losses, of any stock, calused by carelessuess and mismanagonent are 
not mentioned in this paragraph :) Yet, to raise any farm (rog) it is

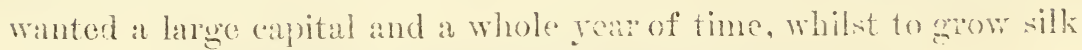
no (apital is neessary, and only 40 dars.

\section{Enow mola?}

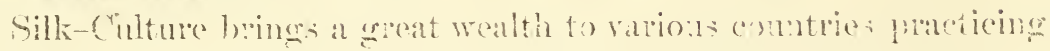
it, and such wealth is dividod, realiy, anong persons of whom it is made mention in forme: proface. And so ; a family of two wrown persons and three childion can gain fom fol to bo dollar (and hy javing a friend's help in the lizst o days, periaps, \$100) ia to days

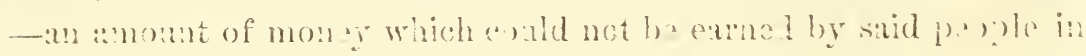
any wher way.

Of eourse, this business is hetter adapted for rural places, whor: the louves an be gathered alway forsh-a thing ahnost inpossible in iaroce cities.

Is for the silk-inoduring-plants [the food of Caterpillares the vadow are refereded to the following pecliminary

Finally ; to those who expect to find in these pages a pandere for swing the silk-Caterpillars from their discanes and general havol

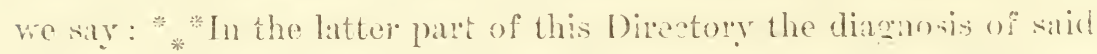

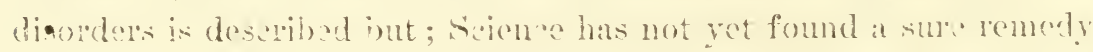

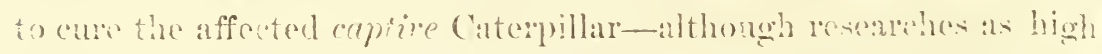

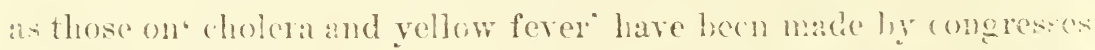

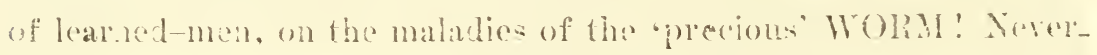

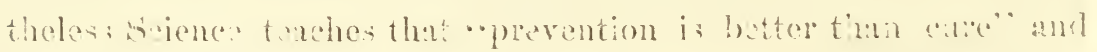
thenefon it with be insisted on "preventive rules", in this book, erene

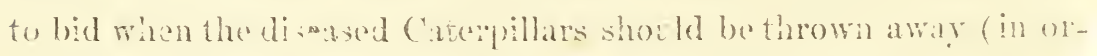
der to prevent loss of time and expensess) rather than to wat for their xarover. With such method expectations", only, an be lost. 


\section{PR}

How the Caterpillar eges can be hatched, and their lavers, reared in : (") metry where the wrowing of mulbery has seareely began, and the notion' about silk-reulture are mixed so badly, purposely or otherwise? Then achin: The mulberry-cuttings, now planted, how lonf whll they stand the inc' (enen of this coll dinate, on when will the parple of this comity know how to cultivate, proter, nums, and

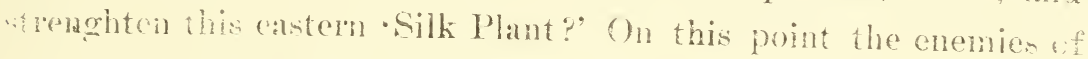
"Amican silk-culture" held the ground a long while, and if it not orerome. they may triumph acrain. Aluo the speculation in mu!licry lips, th yours ago. fell by itself when this eastern plan

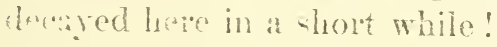

Sow, without silk-food, present?

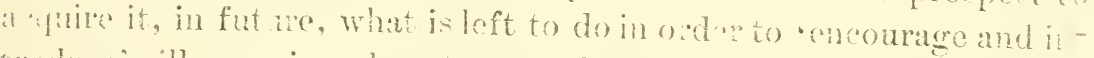
trodure silk-rrowing aluost ererywhere in these Cnited States? A now silk-producing-food mus be foumt, and proper management mat be crepeised.

1. in resard to the management it will be set down in this bool.

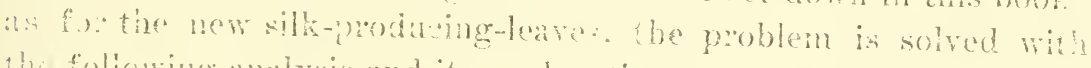
the foldownen andysik and its explanations:

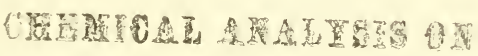

matseryopoves.

$$
\text { p). . . . }
$$

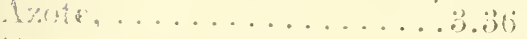

()xisen,

Fiher,

Resin,

$\therefore$ (n)

Water,
03289 - leavos.

$$
\text { i). }\left(\cdot i^{2}\right.
$$

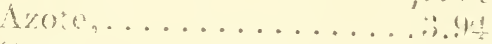

Uxyen,

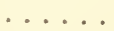

()!

.i.i

$\therefore \div$

.21

.10

100

$10(9)$

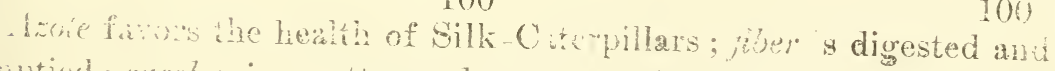

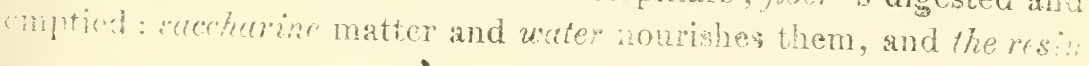




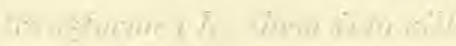

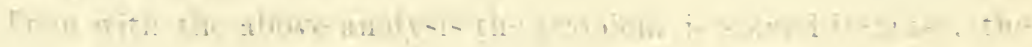

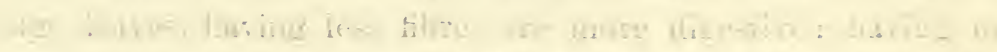

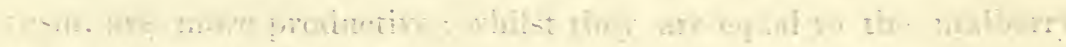

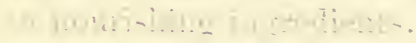

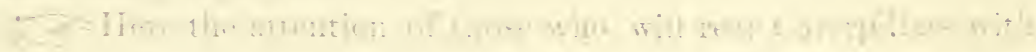

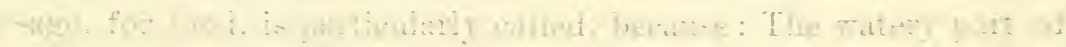

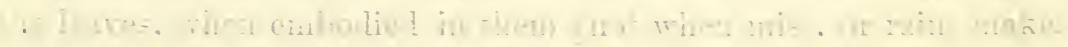

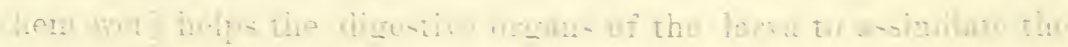

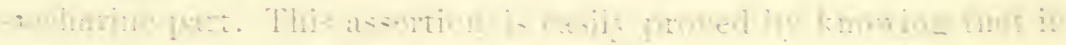

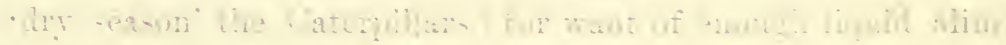

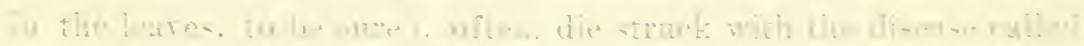

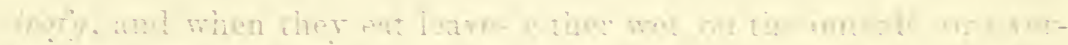

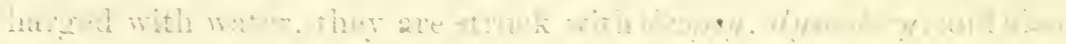

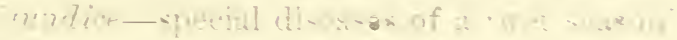

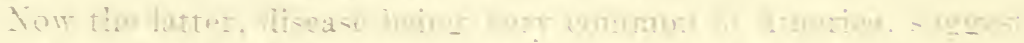

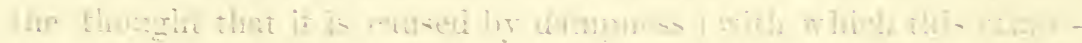

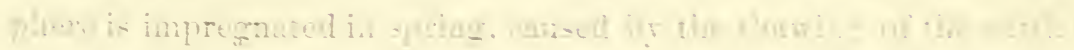

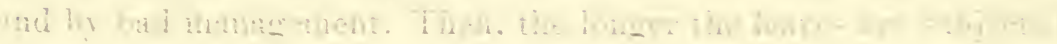

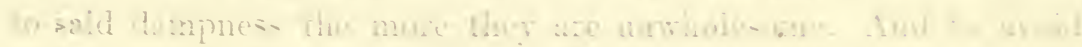

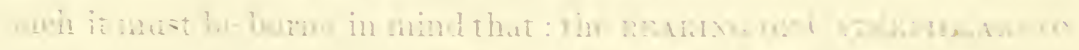

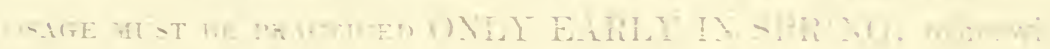

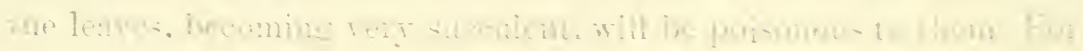

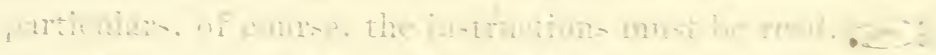

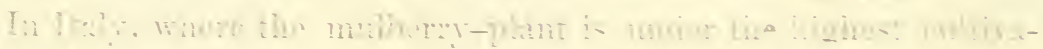

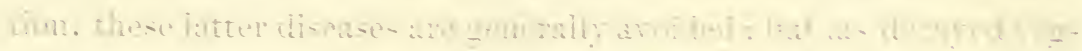

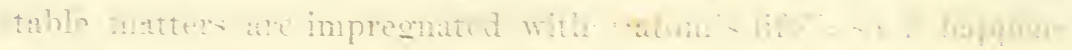

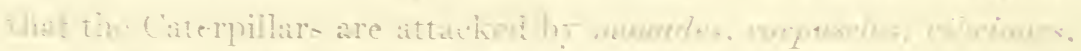

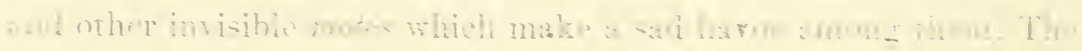

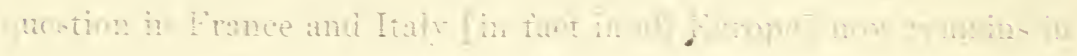




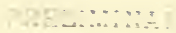

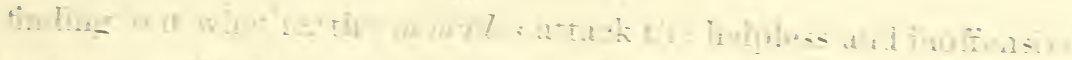

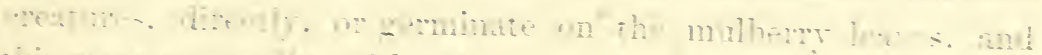

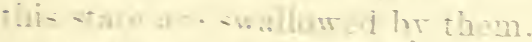

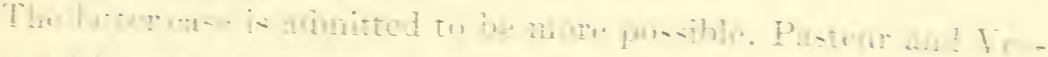

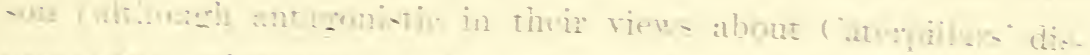

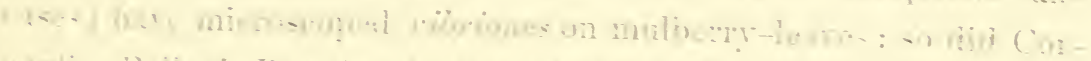

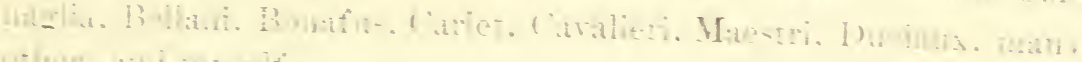

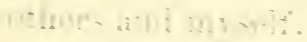

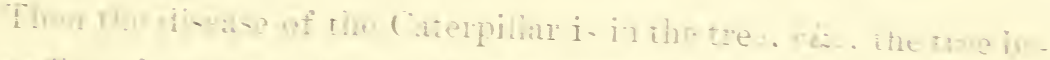

*

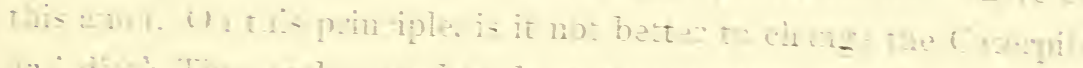

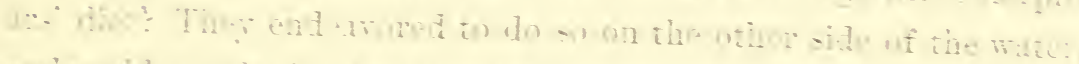

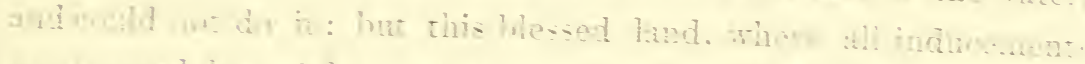

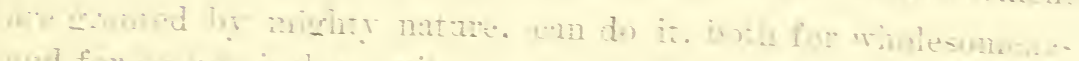

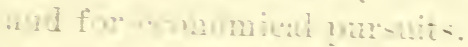

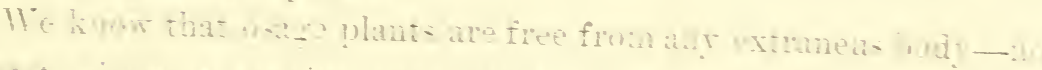

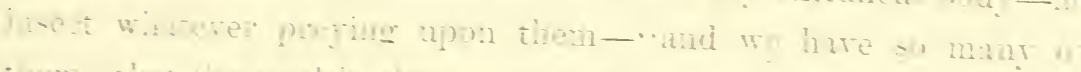

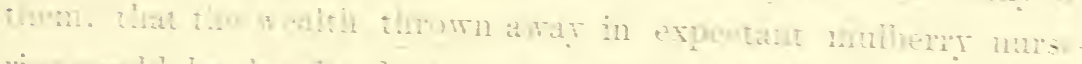

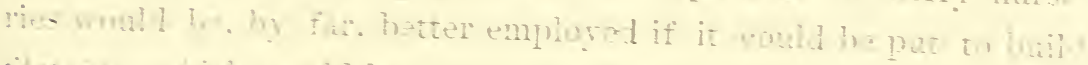

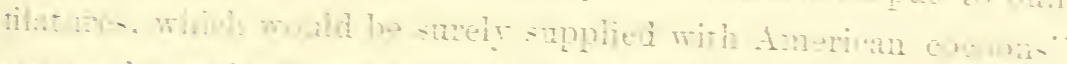

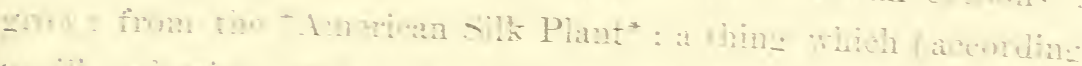

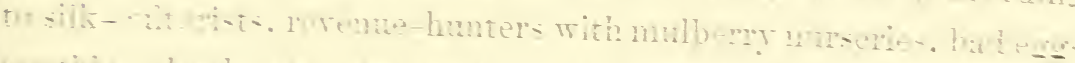

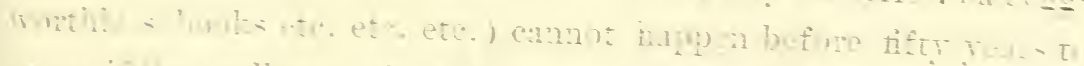

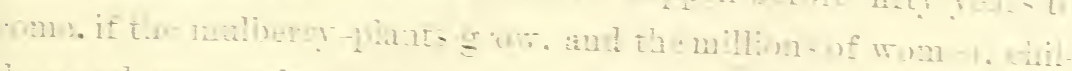

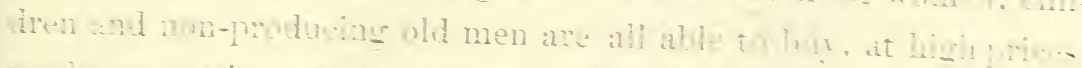

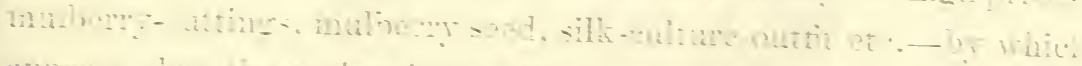

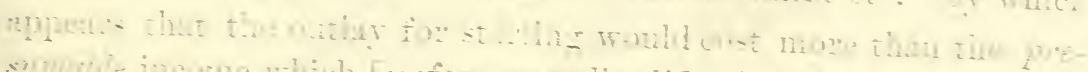

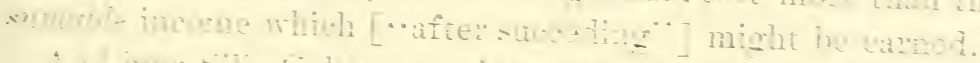

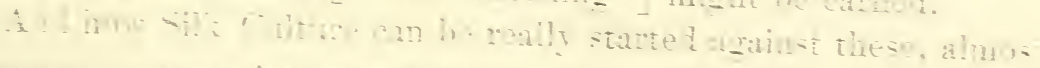

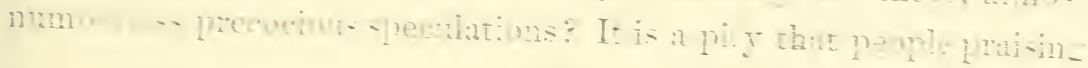


this enployment should make it a misfortune, rathor than an help),

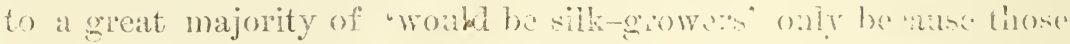

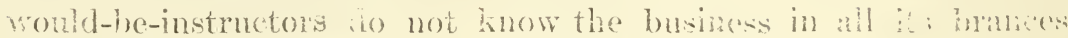
and make light of it.

The silk-business that was started for "othe peoph" is presented now as if it shonld be an industry for the gardener, the somentist and the manufartures. It is clear that things are topst-tury. Mo have so) silk-mowth, but we have inducements to reel it -at thinw whivh would destrey in experiments cren the little silk mased here. o!" at the utmost, allow to be produeed a fow eontw home-malle silkmods. We have an unlimited supply of the 'Ancriean silk plant",

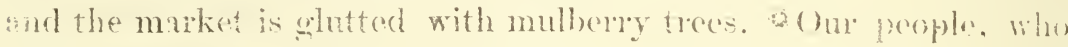
(in not know much about silk-growing, and hare we mones to start this business. are asked to huy (athinet apparatus and exponsive

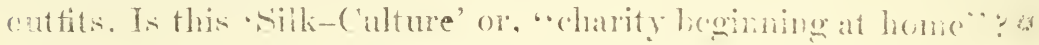

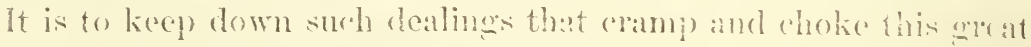

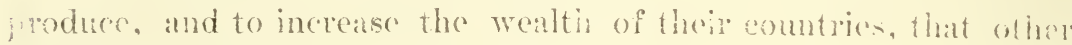
gromment have the lead of it :

In order to grow-silk, the following general rulde mut be pratetoul will are:-

1. Livar the (ateppillars ecomomically.

2 Hatrh the owes when the leaves ane thus:
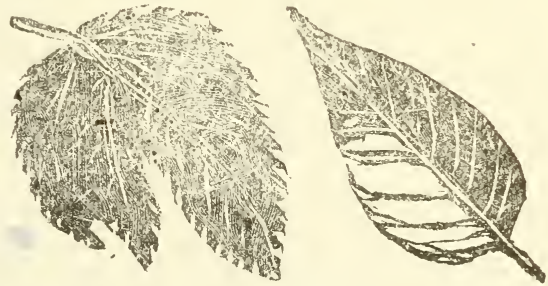

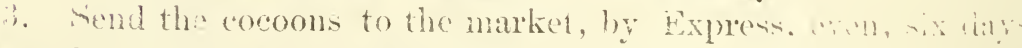

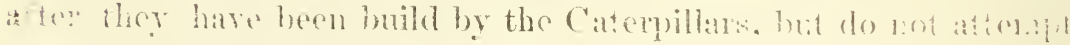


PRELI:AINARY

io stitie them. (Sie 'Conclusion' in end of book.)

4. Lo mo: Caterpillars than can be attended should he reared

i. Hape reproluecd only enough eggr to hatch yourself. and sume of val a w wintares, the following year-not more.

(i. Sell the com me mly to those who buy for 'ready cash' sfte: "xamining the recend pords.

Th: ahove genema!, al bisiness, rules - together with following

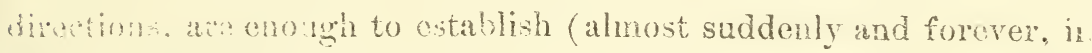
the lritod states) Silk-Husbandry and its good-huck becanse, thos who have mubnery-troes can use their leaves to feer the Caterpit. lars, and those who have none of them can very well feed witl the inmumerable osage [helge] plants-spread, almost, apon the wholo surface of the Union, and proved to be just as useful to grow silk a: mulberry leares.

The above rules are camestly recommended, especially becauss. the following wrong informations have been given, here. in the past

1. It is erroneons to attempt to rear, with 'two persons Caterpillars issuing from four ounces of seed.

2. It is a great mistake to think that, because there is not ant matiet for raw-silk in America, the would be silk-growers unsi raise erss-the s) p. ct. of which could not bo barained, even. for a ronse pair of garters last year and, therefore were thrown by mpratival beeders into rivers.

3. Is in wong to suppose (or to give to believe) that there ir int any maket for wa silk [cocoons] here, and references will bo given on - Gecoad part'.

4. It is and trae, generally, that the cocoons are sold at a dollar a ponnd: an intimation given (under the policy that the producer wonld be at at araced with lower prices) omitting to inform the

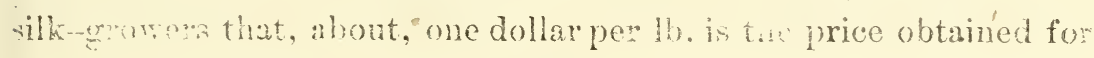




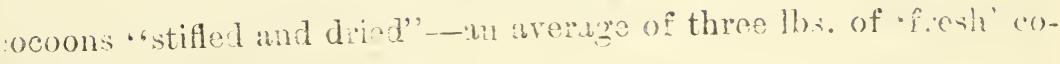
roons to one of 'diy'.

5. It is not to be recommended [ats they do] to sille ard dry he cocoon's before sending them to the market because, the drying orocess', being even more cxact and diflicult than "recling". cannot re blindly eonfided in new hands, and purchasers of cocoons have ontrivances adapted for that operation, and know their business setter: besides 'drying the cocoons' defers the cash.

6. They teach, also, that the cocoons mast, be reeled [i. e. wound off from the cocoons] by their producers, when now a day, latre nanufacturies supply prompter, cheaper, and stronger articies -even the once home-made stockings, and whilst the recling work s a very difficult operation.

"What is the historical standing of silk?"

silk was grown and donned lomg before Sornmox said, * [Proverbi. 31. 22. hecause, in the next 'translation' it will be fomd out that ldam dressed himself with the roughly-carded-like shromds of th. iarvas rather than with the celebrated tig leares.

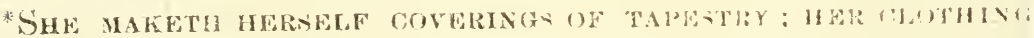
SIIJ ANI PURPLF.* 


\section{SIL - GULTURE DRERTORY,}

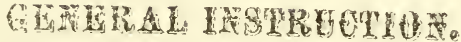

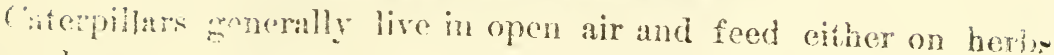
(1). on leaves.

Host of then make silk. but the only marketable silk is producen ly the white silk-Caterpillar, so called for the excellence and hundane of its produce-as well as for its domestic habits, or in door life. But although 'man' was able to subjucate also the (aterpillar, yet he did not succeed to change its natural habits ; declaration easily proved because, when these domestic invertebre? beings' are deprived of plenty of pure air, they surely die. To a roid such a draw-back it has been tried, with good result the herein: decribed swinging

\section{OUTEIT TO REAR SILK-CATERPILLARS.}

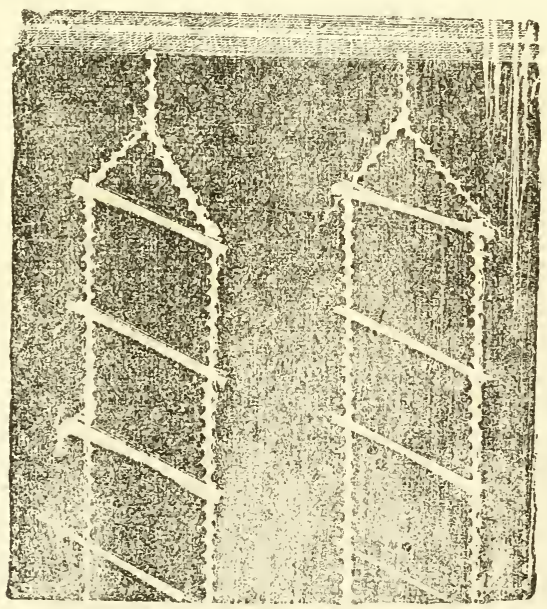

The above engraving represents fwo rack: hanging from hooks driven in the ceiling. The racks are made with : rorked line ['clothes 
GENERAL INSTRUCT:ON.

hine will do well'] and cross-rods much lik e the handle of a hroom: these rods are tied to the lines about 15 inches above each other and should be nearly 40 inches in length. The lines, which must be wa long as required by the height of the ceiling, are knotted below the forking (as shown in the eut) and hung to place in due time.

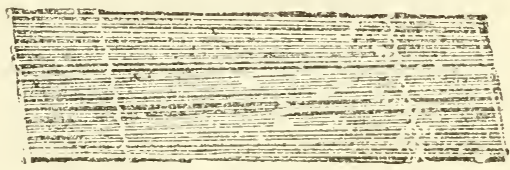

The above sketch shows a shelf upon which silk-Caterpillanwre kept-the little creatures never badging from any place where they may be situated. Now to make such shelves, either" "dry" canes, long straight 'dry' branches etc., or lattice laths about two yards in length can be used. With any of the above materials every person can have the ingenuity of building these "airy shelves" ticing one in. apart, with twine, either the reeds or the slats etc..

Shelves like the above, after having been finished, look very much similar to the slats ofa spring bod, except that the slats of these whelves are very much narrower.

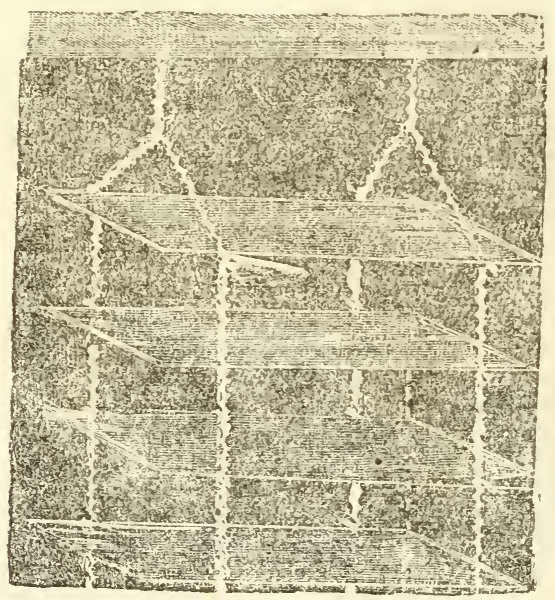

This last engraving denotes the "swinging shelve" set up for 


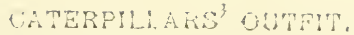

nese. Then, after that the rack [or shelfs holders hare ber put place the lattice-like holves an laid on the rolitant and to taest and the lines.

Another way to make tha sholves is by useing buildiay pape. which, after havin: bren cut to desired length is framed wat hei betreen two strips of lnuber, which form it kind of a donble frame. The framing slips, or shats. need not be heav as they shis: lay on the holders of the racks.

Four. or more tiers hung one above another, as in the drawine form a Caterpillars' suinger. With a 'swinger' of mow than for: tier's a step-stool must he ned becanse, "the botton shelf shouic be at not less than from 20 to 21 inches from the lnor".

One 'swinger" with five shelves [or hurlle's] abont 3ix72? inche: "an accommodate nearly 6000 Caterpillars; thereforo peoplo haviu! other facilities for 'rearing' should prepare in winter 7 evingers.

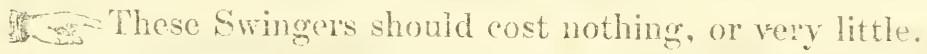

(The outit after the services rendered, the first time, an be asily, stored away to be used in othor years.)

Beven "swingers" should oecupy a romm $1 \times x \geq 0$ and $8 \mathrm{fi}$. Ligh they should be hung in such a way that aftendants may cixcenlat through them freely.

Next to the "airy shelves" Cater pillar-bredom must lave a ham some new straw-paper to cover the hardles: on this paper lay the larvas eating almost always; on this acenthe the paper must be ab. solutely clean and free from any odor or greasy matters. I is in sisted on this subject because a great mun insuccesses are wused by rearing them on poisonous beds. The pyper to bo used th the common grocery paper : 75 cents worth of such is onough to $\cdots$. 
(0),000 ( aterpillars.

At least one third of sad quantily of ctraw-paper must bo pierred y holes cut into it at about ire rights of an inch from each sther. This perforated paper is needel for removing the larvas from their litters. It is very aisi'y prepared ly punching in the paper with an lobllow punch' and a wad cutter'. 'The paperi perfor-

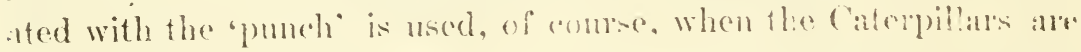
roung, that perforated with the entter" is used when they are full.

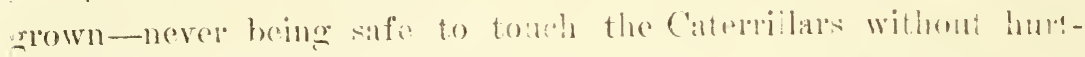

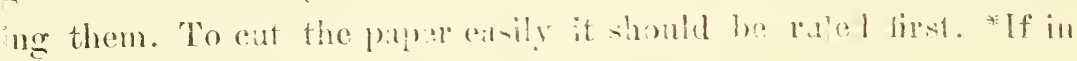

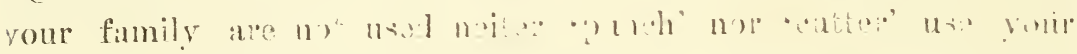

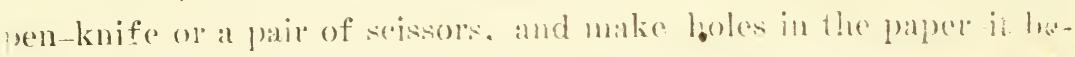

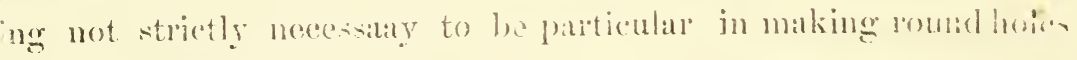
and other "general sugerstions". *

SKETCH OF PEREORATEI PAPRR.

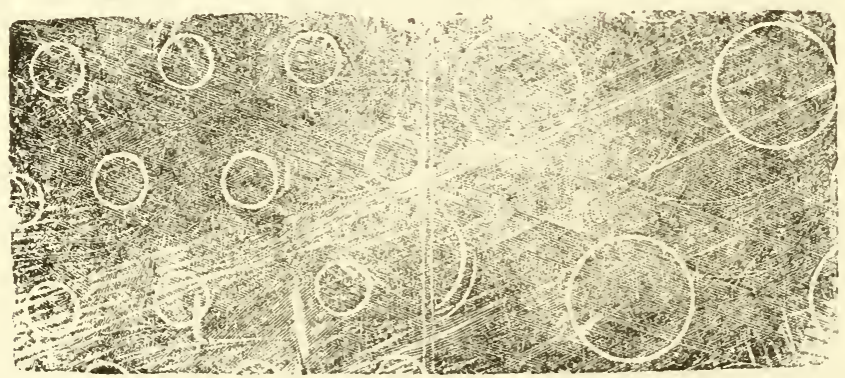

The Caterpilla!s can be removed from their litters also iy mean: of 'shoots' (as expluined in the article on cuscixas) l.ut the li. t: of perforated pay far ilitates the operation.

So, also, these most useful creatures can be reared on any othar mntrivance unlike the described 'swinging shelves' but, these bing the Caterpillars nearer to their natural life

It should he, positively, remembered that all the ferr nead- to 
SDACE, AND COCOONEZ:

rear the (aterpillars must be prepared before that the time of hatehing their egess is at hand, otherwisc confusion sets in, and the art shall not run smooth.

\section{; $*$ *}

(Folt pruper, i.e. building paper, "osts abont 3 cts. a yard; so, on shelf (onld cost, no more than, eight or telicents. Frames interwover with thin wire [set at, about, two inches apart] (an be also nsed, bu: these. as well as any other shelfing. must have, always, the reguirer. surface for rearing a stated number of (aterpillars, and must $h$. covered, also, by the straw-julper needed for removing the litters).

Silk-Caterpillars coming out from one ounce of egges require, ar least, forty six square yards of space. Therefore:- Any clean ans? airy hay shed, barn, unoceupied stable, granary, house-room, of : any other empty building, or room, about $18 \times 20$ and \& of 10 feer high can be arrunged with six suingers, holding four airy sheiven one above another, or with five 'swingers' of tive she!ves each-i: being all the space required to rear about thirty eight thousand Caterpillars, or the issue of one ounce of eggs.

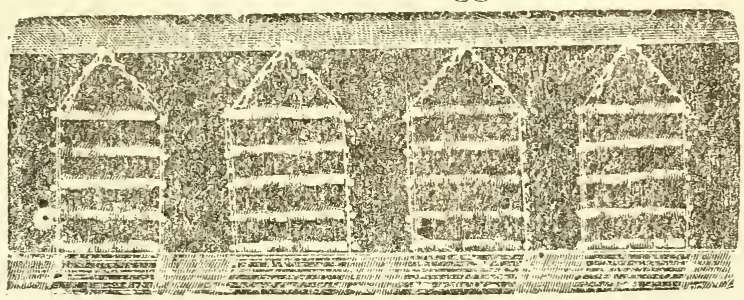

This cut shows one side of a cocoonery-room with swinger's ready for use. Four 'swinger's', hung from the ceiling and two fect from the floor, are seen by the short side, and five 'passageways' : the!s four 'swingers, occupy $12 \mathrm{ft}$., the three middle op aning if feet, the two at the sides $2 \mathrm{ft}$, and all the room is $20 \mathrm{sq}$. ft. Now four swingers put as the above would contain a shelfing sirface of, only, 
40 sfure yards : therefore to rear, about, 38.000 Caterpillars. nother swinger should he added, lengthwise, in the room.

It must be known that the ofoms, or microscopic beings, are suplrosed to be' the wreatest enemies of Caterpillars. (It is a theory which will confute when we speak of the Caterpillars diseases, ut which we follow forprevention sake-the WORM being so precious.) These "atoms' live on decayed vegetable matter, and all other matter: therefore it is extremely dangerous to have these catersillars near stables, hen-honss, pigroies, dunghills, manime and the like: it is also unwise to keep them too long on their litters, because if the animaleules enender in the latter they, the animalmles, will pray, without arail,on the former.

iesides a roconery prepared inexpensively, healthy, and handy with already given hints, breeders should have a place wherein aves, for fodder, should be kept on hand.

The Cafcrpillar's must be fed daily (as shall be taught in - Special sotruction, and can be seen in Tahle on end of (First Part') serral times; but they want [osage or cultivated mulbery. of course :] aves absolutely fresh, yet, ueither damp nor warmed hy the sum, $\because$ in any way fermented.

The leares will become over lapated and enter into fermentalion when they are picked and, then. phounded into the latge' L. for gatherma leaves] as well as when they ale kept, "eventwo or there lums. a a high heap'. To aroid surh troubles, then, and to have lantes

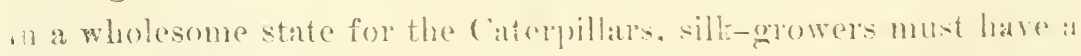
alace, propreyly, adapted to preserve the leaves. A dry rellar or a barn, a wood-shod void of ortors. Woll ventilated, but not elpento 
CONDIT:ON OF LEAVES, CONT.NU ID.

rain, dampnes, wind or the rays of the sun is suitable.

When a small quantity of leaves is wanted pick them in a basket but when the Caterpillus are grown they use a great many of then. and then the leaves mut be either carried in a bag, made of loose anvas-or netting, or must be picked, from their shoots. by the childien at home, after that they have been trimmed from the hedge. and carried there by stronger people.

The last pains are important, only, in the last ten or fifteen day: jreceding the silk-product, and should be taken only by families rear. ing the issue from one ounce of Silk-Caterpillars eggs.

In order to have leaves fresh-but not damp, they should bo collected in the morning (after the sun is very high up and the for is disappeared) for the afternoon, and, then, near sunset should bes picked those needed in the next morning.

in Beware of damp or formented leaves, beware!

Breeders having a supply of leaves cannot fear fogry or rainy weather; because they can wait for the leaves to dry on the treebefore to gather them anew. But, again, the reserve leaves must be kept in a cool light place and on boards, at least, one foot from the floor-otherwise they may be spoiled.

Those who have no leaves in rainy weather should not feed too soon when it clears, because the surplus water not having yet evaporated, would affect the Caterpillars just the sama as if the leaves should be wet on the outside.

Although in the last age the Caterpillars must be fed without in terruptions, yet before that time, especially in rainy weather, they can fast a while if the provision of leaves is all used up: bat this case should very seldom happen if a good supply of leaves is kept or hand. Indeed, it is not bad to have one 'or two' days provixion stored in a fresh-dry place, as it has been said befor', provided that they 
CONDIT: N OT LEAVES, GONTINUEI).

are not now than a foot deep and "not packed down", to prevent which thry should be, gently, shaken two or three times a day.

Our sytem of Silk-Culture is based on rearing the Caterpillars only, after the "spring rains" are over, and on trying to accomandate thein with their natural choices in orje: to aroid too much

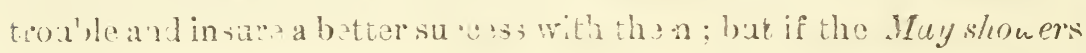
last foo many days, or if the leaves bueome wet by any other storin and the good ones hare run short, then the damp ones '-mus: be recoverd" before being given to the Caterpiliars.

This is done by putting the wet leav on a "clean floor, on dry boards, moving lifting and changing them, with a pitch-fork [or something alike] from place to place uatil they are no more damp: then, after a short while, they can ba served to the Caterpillars.

This evalorating operation can be performed either in open air or inside of the house with open windows-never mind to do it "rear" a big flame" "as smebudy else says, b zause it wilts them.

Another way to atian the same, consists in shaking the wot leaves in 'oper' sheets.

It ha been spoke.n often in this " Gencral Instruction" ahout the 'aterpillars' Outfit and on the necessity of having Goon ress I.EAres, because these are two of the three most impoahant requisites to rear Silk-Caterpillars sucessfully- the third one being [as in everything else] "cleanliness".

By "cleanliness", in this cure, is ment "protection" to the (atupplars against decayed life (that is, the animalcules engendered with it) and moisture-both of which take hold of the litters when too hold, and cance diseases among the Caferpillars. It is then very 
CUCOON, WMMERATIC: GF EGGS, SHPUBS, \&C.

impertant to take away the litters" that is, "refuce of leaves ete' । from the ('aterpillars, which is dome as in special Instruction'.

When the lavers have reached the tim to transform themselve: into butterflies, they enshroud their borlies in cocoons.

They form their shrouds, or cocoons, by putting together, wit: their six "spinning fingers' (or fore-legs-situated bedow their mouth) in a $\approx i ! z " y !$ shape, the resinomi matter of the leaves, by them tramsformed in solid and flexihle silk.

Now at that time the Caterpilars need some "dry' shrub on whire they climb and spin their cocoons; therefore silk-gowers shoul. rut, in astumn or early in spring and dry in the sun , either somr heath, or some eotton-brush, buck-brush, seed-mustard, rag-weed ete. : any of which, if dry will answer to supply the need. If nome of these shruby-plants has been prepared, hay or wood-shavings an: he used. How to employ them it is said later on.

The standard numeration for Silk-Caterpillars is based on the weight of one ounce of gool Caterpillars-cogs. Earch ounce of then mumbers din genoral about FonTy THousine Egas. Allowing an unavoidablo losis in hatching, and through the reang term, goos breeders should bring through firom thirty six to thirty nine thousani and nine lumdred Caterpillars.

称 - One person can attend to Caterpillars issuing from one o\%

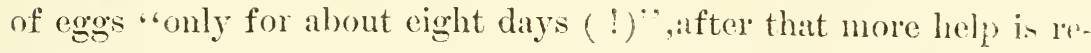
quired.___ Two persons are able to rear ten thousand Caterpillars three persons can rear twenty thousand; _- four, about thirty thousand;- tive persons can mind form thirty six to forty thousand of them. For quantity of food, meals, management and othew 


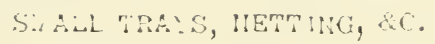

directions it is refered cither to the Srnoption Table or to the forliowing anticles

Besides all the said outtit, ('aterpilans-hreeders should malit thee or four treese, as large as a sheet of staw palper. the being sod to remove the litters.

fo more than the abore preparations are required to rear. from. wirty six, to, forty thousand Caterpillats-the "joblated swingian "ipparatu." saving them form the mnoyanees and raveges of ante rek-roaches. miece and the like: hut to protect them from wirg-

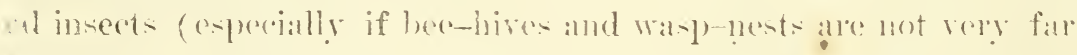

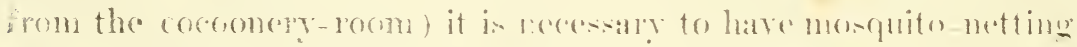
(nil all the speninge- 


\section{SPECHAI ISSTRUATQK $\Leftrightarrow \ldots$}

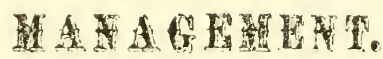

\section{B. - TEMPERATUFE ARD YERTLATIOR.}

The ecomomical m? healthfill Silk-Calture Systm shown in the

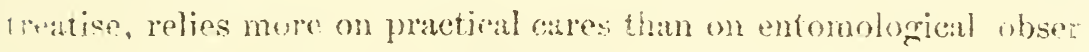
vations: therefore it has not yet been mentioned, herein, any spee nlative' application--supposed to be neoded in taking ("ure of wilk Caterpillars. And, indeed, it shond have been superfuous to do se because Sill-Culture does not at all signify the pursuit of the rea. sevant who incases for observation an 'hemelitre' or an entire. Helo lonta, or at Pupitio machaon with its peculiar cephalo-theca and . . . ex cuse me, gentle reader's, I was dabbling my bygone knowledge or Zoology with the purely industrious noble art of silk-growing, but..

Of conrse, it is known that a thermometer kept in a coconer. suggests the different degrees of heat, which makes the Catmpillar. more or less hungry; but it must be known, also, that when th. Caterpillars are hungry they should have more food. In sich occurrence the thermometer, by itself, does not help much in minging

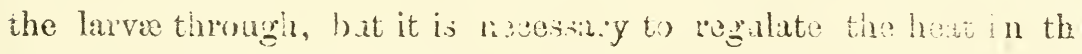
hatching room, [see Intching] when their eggs are inmbuscd artificially-which needs extra expense and knowledge.

About "ventilation" these golden hints are given : Is: the outsids air circulate freely in the cocomery, especially in the sights and 
TE.APERATURE, R YAT:A

tay in which the air is 'sultry'. In these had suffocating days' the somrens will help very much the Cas., for ; by moving the form'r, when feeding is going on, [and in other cares] the latter will be weatly quelieved from the stagnant itmontione.

It is a wong idea to think that hy closing windows and doors one an whe oat the heat; the faet heing that the life-cat is shut ont, ont "the hot stifling ais is shut in". Therefore doors, windows. win-holes, sky-bohts and any other opening must bo kept, in such weather, alway wide open-exeryt if sum, rain, or stang wind preall, in which ano they must be kept ajar.

Then: in stermy weather, or if the rays of the sum should strike

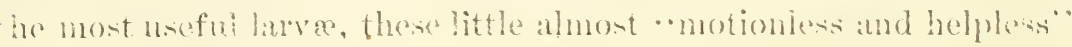
reines should be protected by half shutting the apentwes whereflom he stur-ays, the rain, a morthernel" w hail stomen can come in : set said openings should be shut tp, only enough fo save the (atmpillars [which otherwise mutd not move about and protect fhemrelves] and when the dange:" is over they shond be wide open agan.

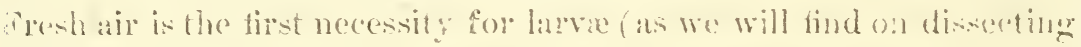

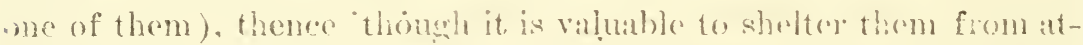

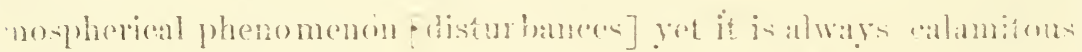
(1) keepl them locked up).

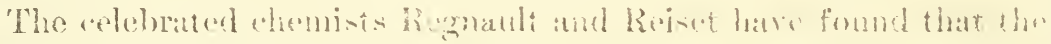

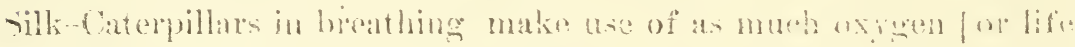

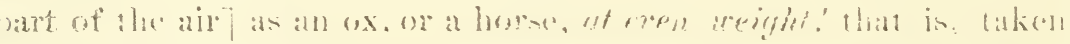

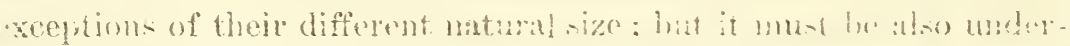

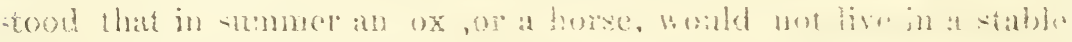

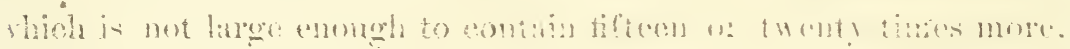
he solume of their bo lies.

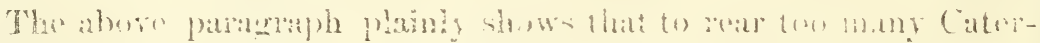

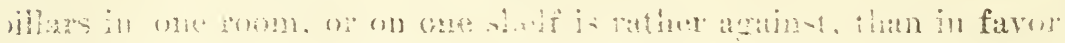


TH. PERATER , VENTILATION, B FOOE.

of thei breathing plenty of pres air. Whichever might be the place for wilk-Caterpillars lot it be well venthated, clean, and fres from obmoxous odors: admit all possible light but avoid the rays of the smm. and when they are full grome amit all the possible at: and shelter them from the whine

With the above treatment the Caterpillars have part ain and Nat. went antride temperature. Now this should he always ezen! "therefore, when the fomperature is "ton high," give to the Caterpilhats fresh leaves pfener and it will lower, and when it is "too low." supply lese leaves to attuin the rescree of it. [See sobistri butiou of Heals.']

\section{II. $\because$ \\ FOO}

Gilk-Caterpillars, like all other Caterpillars, feed on a paticular kind of leaves. which does not agree with the taste of the other.

Cutil lately Silk-Cuterpillaw lived only ou mulberiy leavos, but not all kind of such leaves were whote ome for them. for: if the mulberry-treas were not highly cultivated (by grofing, pruning. manuing with vegetable refuse, ete.) they either domyer or killec the Catrupillars. Wow it is uscless to spenk here abont this king of fornt almost so rare in America that with it wond not be reared Caterillars enough to allow one silk "blow" to eac? of our geatk sex: Therefore we will syeak of anothex kind of food, wheh $i-$ just as good if not bettri, (becuuse more whole:nene) thind the mulberry latres.

This food has been already hinted to the lovers of alk fulture. and is the osege orange leave: As thoy are so willy the where, in the wost and south-west, we do not deseribe thome ftine we gave already their chemical value) but we will tell oily at article wh theuld ba the properties of goof fodder for will allars, 


\section{FOODm(}

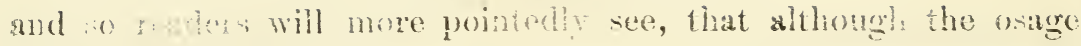
leavon an hard to be collected. yet they beat the easily gathered

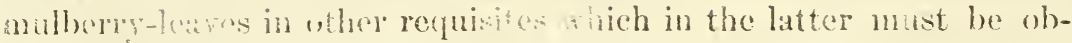
served lut in the former are net ne. ied.

(ioor for for silk-Caterpillare ange or mulberry) must have the following poperies.

First: It must be good, vi\%: It must be of a "deep green," with losed. the fiber, and must be joduced from healthy and ronk

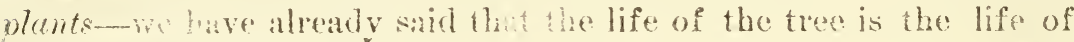
the Catcrillar.

recond: They must be neither wet nor damp, deayed, yellowish, or with rustike spots, mildow, overheated, \&e.. \&e.

Thire: The Cas. stould le fed through all their life, posibly. shay with the same kind of leares--a plain impossibility whon the following is pondered.

Then here below we put the different variotics bebonging to one

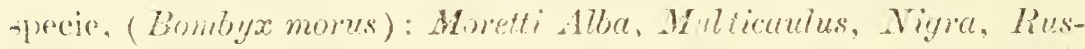

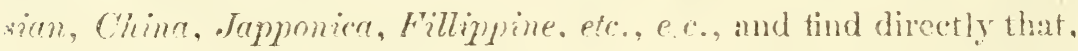
as high eivitation hat been tampering on the natural rights of the minal kingdom, so it has also dons on the proclivities of the regetable one. No wonder if the sih-cas. alo struk with torible mal destrutive epidentes. What it is puported to has heon at white-bery-producing-malberry-tree hat becme now changed by

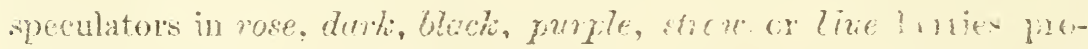
ducing malberles, by grafting over and over again. And an be

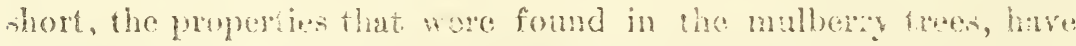

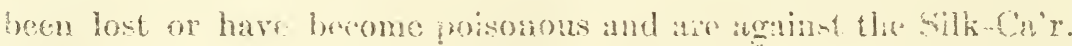

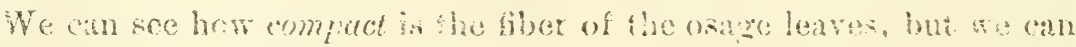
mly see how open is that of the wabury. Mow and it he dold,

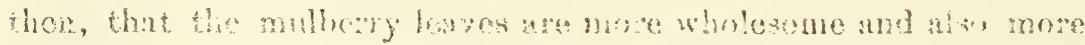




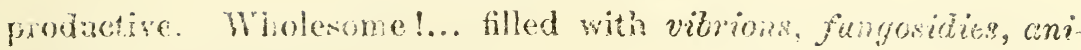

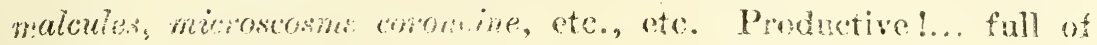
bolem, grop, meshes and water reservoirs.

After the above fast w w lumerymen we sat: Stick to one varity of mibery and hetere it with aproved cultivation, and then. within fifty yairs, this rast country, perkaps, will produce muek silk form mulber'y-trees. But to Catenpillar brecolers, we add. rather than to wat fifty yenrs, go ahead now with your American silk-plant, which does not need to be selected before you feed. which never becomes yellow or covered with "rust spots" os "sweets," and is avoided by all other insects and atoms.

To young Caterpillar's must be given young leares not quite decply green ; to grown Caterpillars must be given older leaves and of deeper rolor.

This management is not hard to aceomplish, when it is consid ered that the Caterpillar's egres are put to hateh ahout tein days afte: the troes have commenced budding. [See Ilatching.]

The dampor the season (if the egras are hatched too early or if "the season is late") the more it is necessmy that the leaves must be thoroughly fiesh und dry! Therefore they Must xot ne didTHELED BEFORE sUNSInNE OR AFTER scrser, especially when dew or fow make them damp. We have already told how to evaporate them when they are wet by showers.

\section{III.}

\section{DISTRIBUTIOR OF MEALS.}

As a rule *the Citcripillars should receive steml!f Tight meals which should be repeated as soon as they are eaten.* But as it is of no use to give a rule, which will not be observod. we say: it is absolutely necessary to give at least six meals a day, at about the following times: The first at sumrise-6 a. m., or thereabout ; the 


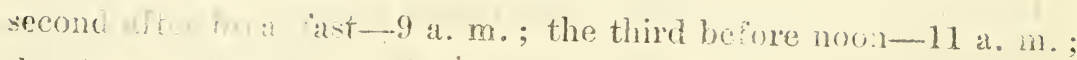

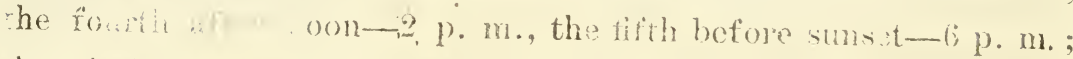

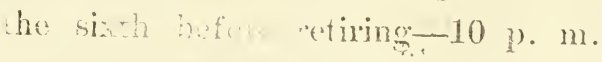

-Whom the ('ateppillars aroj oung they must have one single

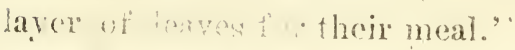

Then put o a then leaves, one after anothes', and if they devour hem in ons -tralt of an hour, focdagin.

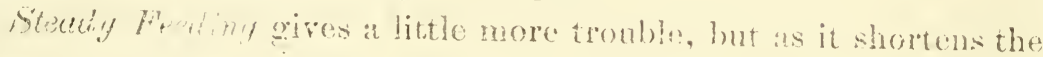

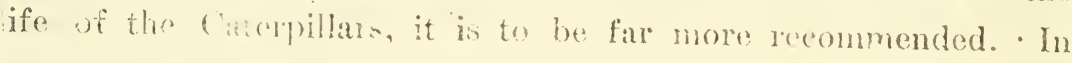

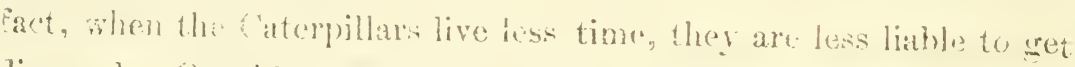

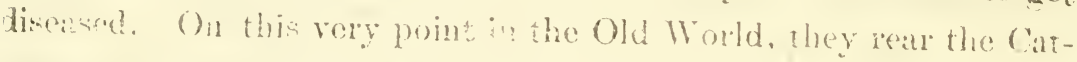
rpillate by moans of ertificel heat, the comtrisances to obtain

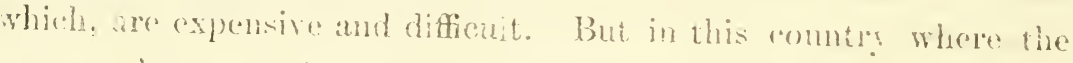
summer hoat sots in hofore the regetalion has altalinod its full

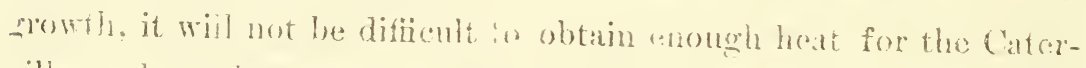
illars when these come forll: at about the litter part of Apri!. [n thin fase, if they are fed and well cared after, they will spoin - heir coseons in about thirty-eight days. Therefore. whon tho

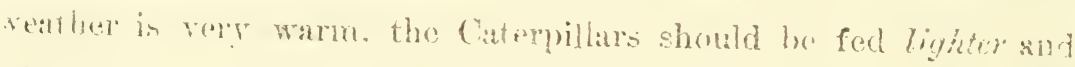
oftemer, and. When the nights ate also very wam, then an extra feed

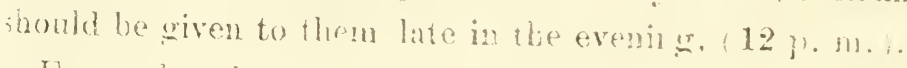

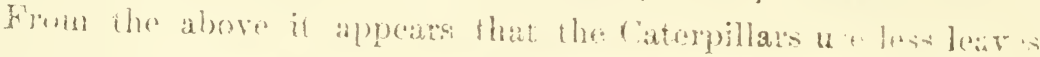
when it is root than when it is warin, but they use the sa 1 i 11 -

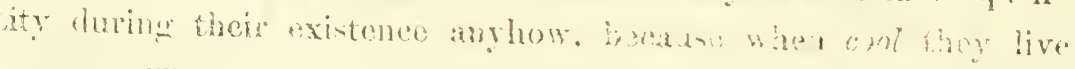

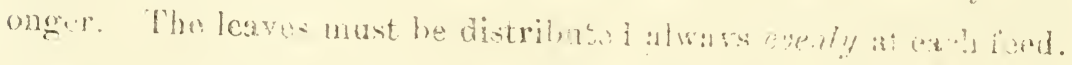

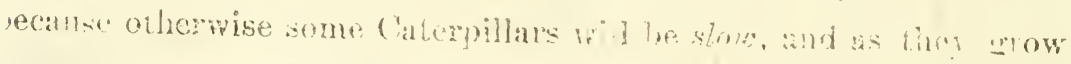

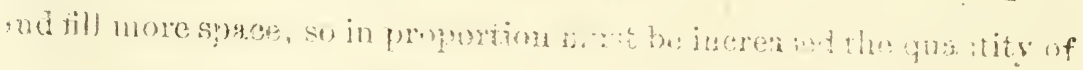




\section{B $7 \mathrm{~T}$ ล}

leaves to be distributed. Exceptions to the above will he found in a sporal articke edited for each age of the caterpillar.

\section{II.}

\section{A}

One person wan attond ter Caterpillars issuing from one omnce of rags, only until the second moutt: after that period it is needed another person to gather the leaves, and at the last ace (after the fouth inoult), at last, two other persons are necessary to collec: loaves and another to bring them home and help also in changing the liticrs, preparing the cottages, \&e.

a- $=$ The original Japanese breed are rather lazy in climbing to their cottages and sometimes would spin their cocoons amongst the litters, thereby depreciating their (the cocoons) value; therefore an extin hand should he required to push them to the cottages witl the means shown hereafter.

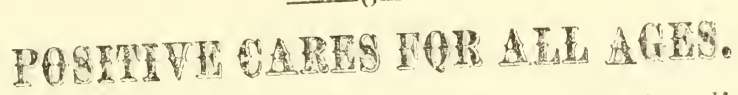

Good food, pure air, much space and perfect deanlinesis ramnot be aseful if caterpillar breeders do not know the followisg particulat's:

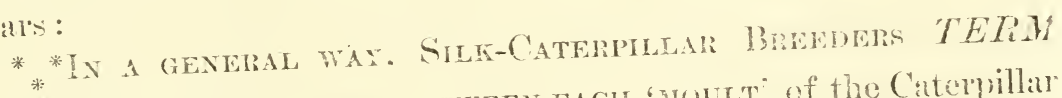

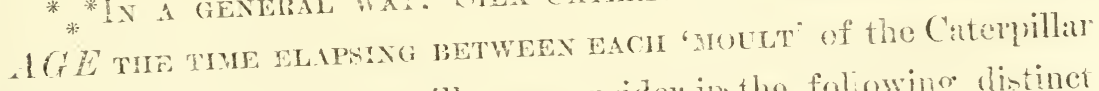
the rearing of which we will now consider in the folowing dintinct articies :

\section{I.}

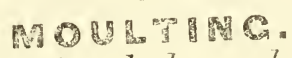

Caterillars notut that is, shed, or clange, their, almost invisihle, shin) four times during their hort life.

When they reach each time of xoutuxg they loose their apetite. and limb over the loares, without eating them, where they take an 
MOULTIYG, CUNTINUED.

Anost upright position with the forcepurt of their body, as will be sinwn herein with euts

For a day or more prior to each chmge, the laren (†) secms anguid, refoses food, looses its benutiful pearl-white color, and andergoes this important change.

Fastening itself by its logs to the surfate on which it stands, it twists and contorts the fore-part of the body until the skin splits flong the back, and by progressive contortions and motions it withdraws the whole body through this rent.

The skin, when cast, is often so entire that it may be mistaker: for the larva itself.

Afier each 'moult the lama appears weak and languid a gain, while the whole body is extromely soft, and is very wet. A few hours' exposare to the air, lowerer, gives tenseness to the mem-

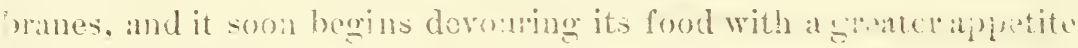
than erer.

Although the body of the siik-('aterpillar increases in size irom day to day, yet all its segments become, daily, lanoe tense and comparet, until the enveloping skin is no longer capable of containing them: then it 'sheds', and directly after the moult the hody grows more rapidly. So, people will hardly halieve that the boty of a Catepillar that has jast mo alted is, after the first moult fluree thes larper than before the ehange; - after the sacond weighs four times as much at it did hefore:-after the third weighs twelve times more:- -after the fourth, twenty ;-- when full grown, forty.

(†) The larva is the state of the insect immediatriy after it is hatched from the egg, in which condition it eats voraciously, sheds its skin sercral times, and has the power of locomotion, but not that of propagation. 
POSITIVE CARES FOR ALL A.GES

Now, when the Caterpllore are at this stage, in which they main from 12 to 24 homi, they must not be ford, othorve (as freir metamorphosis is : Ivancine and they are unable to go abotit) boy

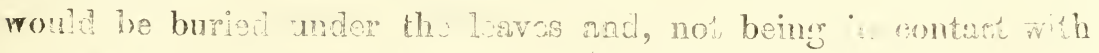
the an would bn a longer time to 'be undressed'.

Besides, it must be known that if the Catcrpillars a de tot kepterenly, by means the ruks iven below, they canot noure "rolmost, al' at t'e same 'ne" : thenee, it hapens that, ou the sane litter, or shelf, some undergo routwa and some are unalie to do it: in this ase, of comse, a number of then dives not need food

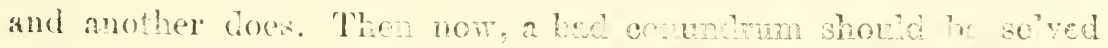
hecause, if the needy oros are fer, those not so are injuried, being not in contact whth the air; and if, to avoid such, there are not id, the othere wil suffo for want of food. To avoid this duficulty in reang silk-Caterpillars it is needed eveness on ear h shelf.

II.

\section{E}

'Po keep the Caterpllap; arraxy mat he observed the following rui. " which, allowing more heat to thome hat hor Ieter, give them a mish to roach those jssued from the erms soonur:-

1. Those hatched the first day mus be put on the low so shelf of: wringer and kept all by themelvo; thow hatehed the secand day ment be put on the nert shel; those hateded the third day on the thid sheli, ete.

2. The ood must bo distributed evency io all the Catsmillars, i. c. genty spreading (aboat) the same amount of leaves to all.

3 . If after one or two hours, all the Caterpillars occupying a shelf are not resting to moutr, those which are yet homgry must be remored from said shelf and put on another-this operation be-

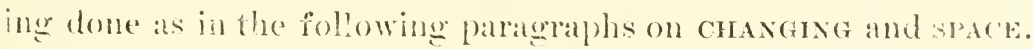


Whan caterpilitur are treated as above, during their life, they will not he trombesme, berane breeders will have always a num-

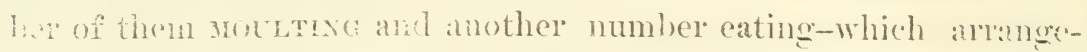
mat permits as gocal distribtion of cares, aroids waste of foorl and favor's the health of the Caterpillars; also lessens the work.

\section{CINA $A N C$.}

When the Caterpillars must be chovere from the old liters (which in explained herein) they must be attracted by fresh aplefizing leares to some plare. Therefore, when they are young they mast be attiacted with the leaves on the perforoterl proper and when old they an be cuaxom by feeding them with yome shoots on $\therefore$ mali inancher with fiesh loares.

It las heon alveady explaned how to make the perforded griper. Non take a sheet of such palpere and lay it on the Caterpillars; or better: cover all the Cattrpillars laving on a shelf with sheets of such power, situated one urext to another ; then spread leares on the sherts. After you lawe donesos, repeate the same doing with all the other Caterpillars that must be removed; then wo to the shelf you tirst "springled with leaves" and see if the greatest number of the Caterpillars have cronded through the holes on the fresh leare... If they did not $\therefore$, wait a while: if they did, take one of the "perforated sheets", hy its diagnal cormers, and carry it to the nearest emipty shelf. Eay it thene and wo to take the other's and put them one next to the other until the shelf is covered with them.

When that is aceomplished, look if any Caterpillars are left in the old litters. If you find any of them, remove them to a sinto

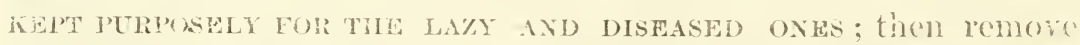
the litters, either molling up, from end to end, the straw-ingrei" whereon they are ol sheet hy shest. 
POSITIVE CARPS FOR ALL AGES,

Ty a lf the litters of the young Caterpillars appear woll cove (res? with silk-weh, it indieates that a cood silk producing breed is ķept on hand.

After the above, the shelf is ready to contain some Caterpillars: agam-and so on with all the old litters and shelves.

And that is the operation of cmavang, or, cleming the litters of the Caterpillatis.

If you tind difficulty in removing the "pelforated payers film with (ateiplillars, wse half sheet; or hetter: pull a sheet on a smen tray as large as a sheet of strue paper (of which tray we spoke in No. 5) and then lay it on a clean shelf, as already written.

When the Caterpillats are full-grown they an be suplied with young shoots withont had thoms-if they are fed on osage. In this rase it is not necessary to use the 'perforated paper', because t? shoots an be taken on the rays and then replaced on another shes.

Sometimes the Caterpillars do not motut all within one or twe hours on the same sholf: then again, after mocetrix, they mot have more space than they did before: therefore it is evident that whon they are changed then more space must be wiven to them, ise"ause after each yorim they grow laryer.

$\therefore$, if a shelf is erowded with (aterpillars it shonld be coveres twice with "perforated paper", that is, a munber" of the Catcipillans must he removed with the first laying on and the rest with the sorand (which makes two shelves from one): the few terly omes to be put separiately.

\section{IV}

\section{S.P AE.}

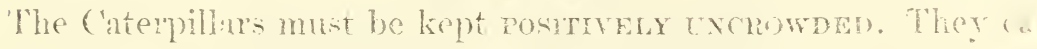

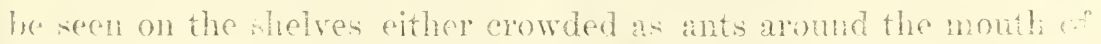

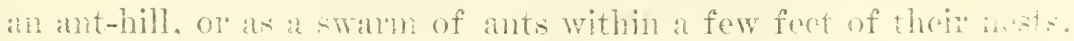

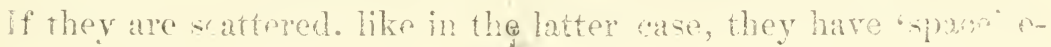




\section{POBTIVE CARES PUR ALL ACLE}

nongh: but when they are almost one abowe another. like in th former, they must be divided. This is done not only when the catrpillars are 'changed' hut also by putting fresh leaves where they appear swarming and, after a while, removing said leaves (or shoots climbed by Caterpillars) to a more open place of the same shelf-a way to keep eren all the calivas on one given surface.

Should a whole shelf be orepromeled. then it must be made spurse at once, occupving one or more shelves with its superabundant ('aterpillars-in this ase to be removed, quicker, with the "perforated paper", which must not be pulled, in this case, but must be lifted in order not to hurt those laying under it.

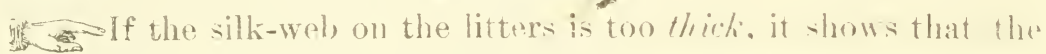
Caterpillars are too many together (i.e. have not enough "spara") and therefore they must be thimned. 


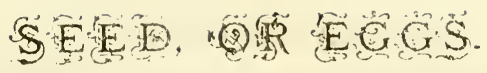

Owing to "monopoly and fraud" Catemillars' egses are nor becoming more and more unreliable. In fact formerly it wasonly important to detert worthless eggs, but at present-finult of th: importers of Japanese medicated silk and inferior breed of Caterpillar-erges one must look out for the "cheap bred" (given away: even, free to depreciate the value of the American silk) and try th rear"only those Caterpillars whose silk heing acknowlodged to br. the best command better prices.

In order that pople may know what hing buy we give the follow. ing rules :

The examination of the seed becoming more and more impurtant, must be made first on the outside, and then, an little time befor hatching, with a powerful microsene.

The principal characteristics of good seed are, externally: a perfect resemblance among the egos, viz. : they must be all of the same size, hav all almost the same color and the same iittle de pression in the middle; they must also stick to the place where they were laid by the butterflies and must be absolutely odorless. Japranese and bivoltine eggs are nsually smaller than the Italian an nuals, "so being also their coming Caterpillars." If the oggs wer laid we next to amother, regularly, it is a proof that the butterfy laying them was healthy and lively, but if the eggs are laid in little heaps, it may signify that they night have been sickly.

Firutul egas belonging to the yellow-cocoms-best-problucing breed are like the white pots in this ent.

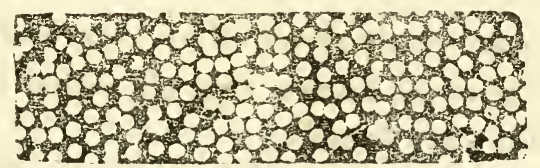

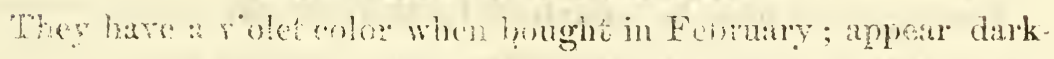
$: 3 \frac{1}{4}$ 


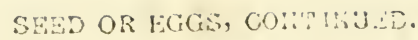

gray when bought in March; bought neatr hatching time they a. pear light violet, but observing them elesely their went is cleaty distinguishable and their inside is neary black-which is the little Caterpillar hody ready to eome forth. Besides, every now and then, a little crackling, caured by an invirible split in the shell, oun be distinctly heard among them. These cogs produce only once a year, no matter what seientific process night be employed to force them to life oftener, and, thorefore: are called anmuls. Forty thousand (round number.') of them weigh one ounce.

Fruitful egrgs of the white ancons-producing-brecd have the arme characteristics and weight of the alove. The white cocoons of this breed are very fine, but owing to the fact that they are easay soiled by the Caterpillars, and in handling, their prices are atways cut down unmercifully!

Fruiful eggs of a breed producing cocoons white, light yellon and deep yellow, have a light olive color: these cocoons are the pest of the silk actually raised here in America! liggs about the same weight.

Fruitful eggs of all polivoltines, that is, eggs that will hatch over and over again in one year, have about the same color of the yellow cocoons breed, but about $45,(00)$ of them will weigh one ounce. Cocoons lighter than the annuals.

Fruitul Japanese eggs, light green, straw or white, have color bright violet, ete. About 54,825 of them weigh an ounce: Lighter cocoons still, and the cheapest!!!

Cnfinitful eggs are easily detected by everybody when they are dried up; but it must be known that all, either reddish or yellow eggs, are unfruitful when bought.

The eggs can also be exanined by their sperific weight, remembering that, one gram of impregnased eggs contains about 1,250 of 


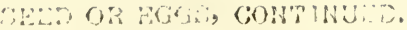

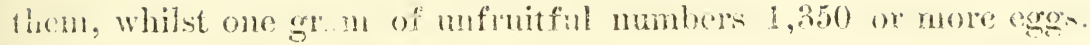

Iniffereni breed an be knowit by the following mens:

Palso a fow expos and put theme on a small piece of elase, situated

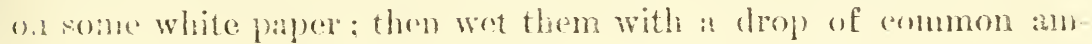

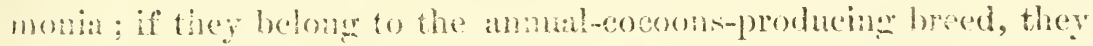

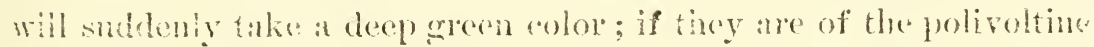
apeon brecel, they will take a light hown greenish tint; the white. and yellow ammal do not ehange colons.

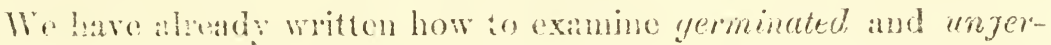
minated argers. breas of crows. number, ete., and should now tels

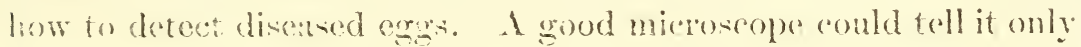

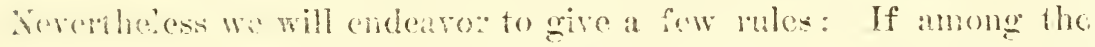
wors you bay, you detert some of them haring small lithle black spres on the shell, they mast be refused becaluse they are infereted

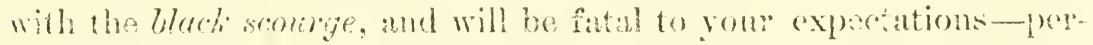
haps just when rou think that theor latehed Caterpillats are going

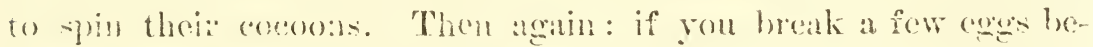

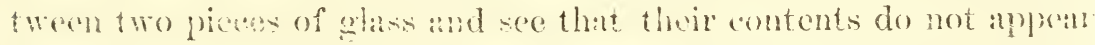

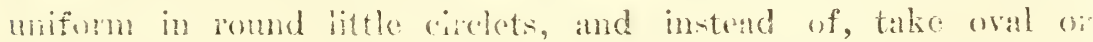

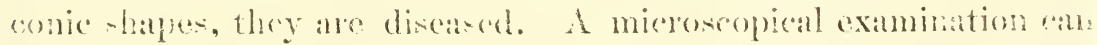

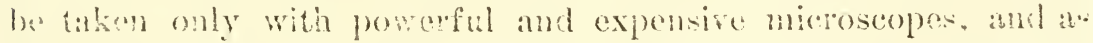
these ane not at the sortore of all the perple. we dont grive hare an explanation about it, hophos that what we hare sad here above night be of gool nse to all.

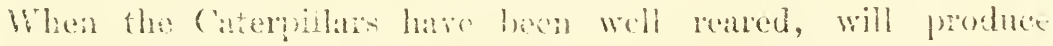

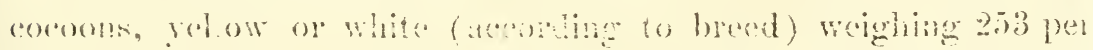

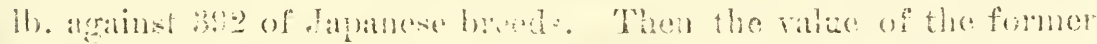

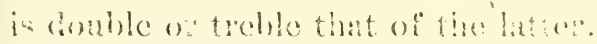

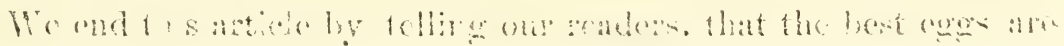


HATCH:ZG.

those described as abore and that they can be ald on picese of paper-boad, paper or linen, whe eon the Caterpilars lad them.

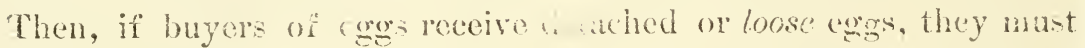
be more careful in the examination, because sometines they are inaudulently prepared.

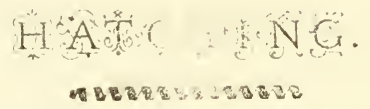

The early ha ching of vilk-Catipillats eges brings around many failures; people foan the wam weather and believe that the ('aterpillars fear it also, therefore, they will hatch carly, and when it is too warm, they shut up the openings of rooms containing worms and therein they choke the precious creatures. Without heat the little insect does not come forth from the egge, is not lively when young and camnot build its little silken house. Why then hateh the eggs before the full disappearance of cold weather? It must be remembered that the Caterpillars hateled in April will not produce the cocoons before those hatched in May ; the former will live from forty to fifty-six days, whilst the latter live from thirty to thirtysix, and hoth of them wil have eaten the same amount of ford, with the difference, that those hatehed in April, have requirod nearly two months of attention, and, perhaps, expenses, whilst the latter have required only ome month. Do not fear the heat then, no matter what is said against it. We have reared Caterpillars here in the months of .July and August, and have had good produce after the lipse of trenty-four days only. (Whe? too wam do not forget to feed lipht and often.)

Hatching must begin when it is known that cnough little leaves can be gathered and supplied to the risirg little Caterpillar.s. Then 
HATCHING.

when on the lotb or 15 th of April we see the trees finily budded, we must bring the sed in the hatehing room. (Any room will do only it must be supllied with a stove, thermoneter and shelving, whereon to put the egges and keep the yoming woms for a few days.) In the first four days in which the seed has been put in the hatching room, the temperature mut be, night and diy, not helow 50 degreas frt. and not abowe 55 ; in the next four days, not below 55 and not above 60 ; in the next four days from 60 to 65 : then add a drgyee of heat every day until it has reached 77 degrees. This last temperature must be kejt in the hatching room in the time the Caterpillars are coming forth as well as through all their first age.

The seed wa be put in the hatching room, cither stuck on the paper bourds where they had been laid or in a little squate box as here below. In both case: the oggs should be touched with a solution of common salt in order to destroy any corpusele which might have wintered on the shell, and atso in order to weaken the shell and so help the little insect to pieree thromgh it. This bath of salt water is applied to the egry stuck on palper, ete., with a soft wet rag on sponge, hut if the rygs are detached on loose, they can be dipped in salt water outright, and after having baren kept there for a comple of nimutes, they must be spread to dry on blotting paper. Whon they are dried they must be put (each ounce) in two boxes six by eight inches, (or ten) about one inch doep. Orer this box must be dixed a piese of taldan or white nosquito not, (for parposes explained in the artiche on fins aye) and so prepared they aro kept, as the engos on puper in the hatehing roon. In the laper of

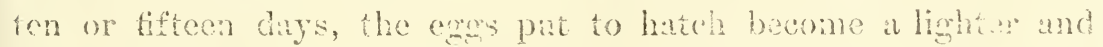

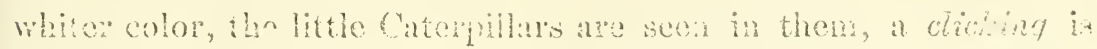




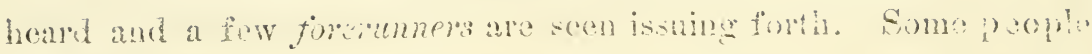

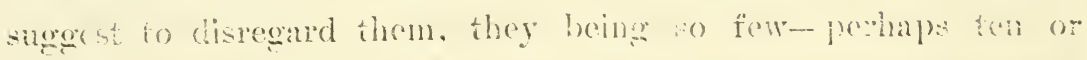

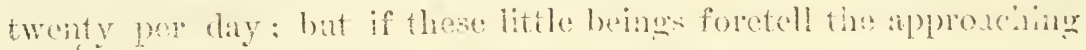

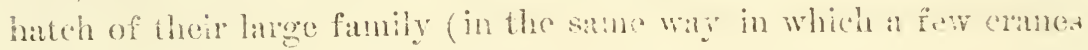

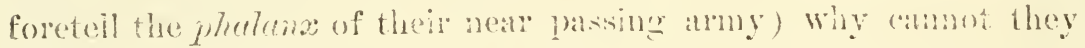

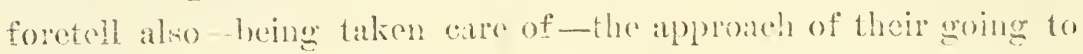
apin their acoons? It is no trouble at all to thke ente of steh at few, and they will remind you of the sure time in which their kind re going to hateh, to shed their skin, to eat, to be voracions, to spin, ete., therefore be nercifut with them.

The young insects come forth ahmost always at the second and

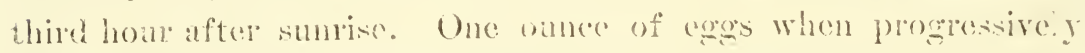
Latehed, lakes two or three days only to produce, but otherwise aakes fomp. fire and even oight days-in the latter cascs the rearing hecoming more difficult as we explan in next article.

The rup about the warmb of the weathor, wiven at the houd of this article, cimmot be applied to the many different climates of the States possessing osgege plants". becallse the Joares of owage ane "dangerously affected" hy showers and the hot rays of the sun.

On this aceount (to aroyd the, almost sud lenly, "thicliened sap)" of said leaves) it is absolutely important for the prosperity of silk Culture in those States where the temperature is tos inconsiant in stard the hatching of the egos when the laves are just hudding. In this way, it has been experimented that the Caterpibias come un ail right.

But, now, must be usca artifucial heat. This an be abily pouvided either with the howne or with the kitchen heating apraratur sny of which being ued must have a degree of moisture, which is procured by constantly keeping on the stove a kettle full of water, eontaining a little pulveriged lime. WORMD do alwars well in 
F:RST AGE.

in newly white-washed houses, and are never reared in the kitchen. To keep the Catelpillars warm by means of the direct heat emanating from a cast-iron stove [especially if new] it is to procure the Aacirlity in them.

FAULTS IN HA TCHING.

People unacyutinted with Silk-Culture, detach the little egros frour the place where they were laid, rubbing, loosing and crushing most of them; then they put them under the mattress, in the sum, or is. their hreasts at a temperature of 85 to 95 degrees; this is not hatching: it is half-cooking the silk-Caterpillars' eggs-which are kept in a little bag wherein are mixed up bad eggs, shells, little mulberry leaves and little worms together. Then this is the foundation of the silk-rearing disasters, and it is no wonder that many breeders (who attempt to rear with another person and with such bad hatching process, Caterpillars issuing from four or five ounces of "ygs) searcely get ten or fifteen pounds of bad cocoons.

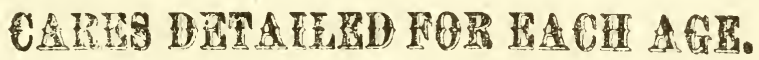

\section{FIRST ACE.}

Caterpillars just hatched from the eggs are as large as in the cut.

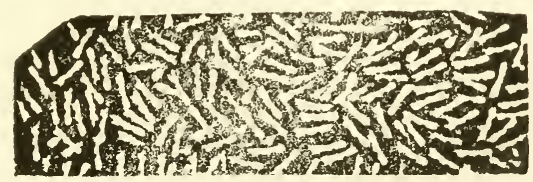

If they have vitiel a deep chestnut or a u.tis color, they are healthy: but if they are reddish or blak, they have been hatched ladly, are sickly and will wive trouble; better thow them away. At about noon and six homis after, gather the little Caterpillars. putting tender ange o" mulbary leaves on them, or on the mos- 
: : P S A GE.

quito net-about whele has alvoady been spoken of.

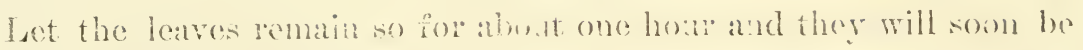

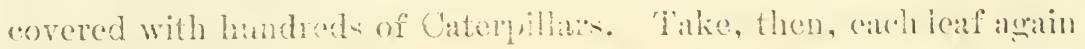
rery carefully and from the perdicte, and lay ibem one after another on a sheot of straw paperi, which you must have ahrealy situated

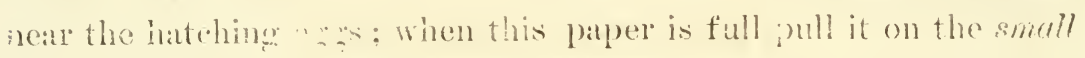
fro!y and sitnate it w a lower shelf, and there l': also all the other

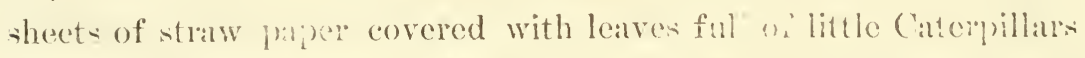
yellered the timt time. When you gatlier the Catenpillans the arext dity, put them on the above shelf and so on. Such treatment is needed to kecp thein r "ren.

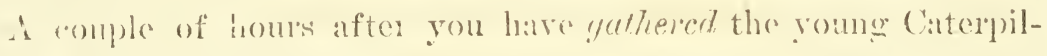

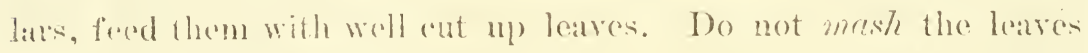
when you cue them up, but after having made a little bunch, cut them as smali as a hail. if possible, with a sharp) knife. Lay, then, these sharings, erenly on the ('atelpillars and repeat such ati soon as they dry up. Whach you feed allow always mome room to

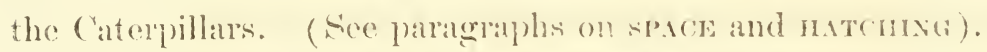

The color of the little Caterpillars orignate from hairs, with which their body is covered, althoneth their skin ire really whitish. and their snout black and shining. When they are three days old they become humgrie:, their head whitens and their bodies are a dark yellow. On the fourth day they appear yellorriste-blue: on the fifth, their appetite lessens, and on the end of the sixth day they rest for moulting. The first cut on next page shows the Catei-pillars in a momlting attitude. which is stillmese, head suollea, forepart of body elevated.

In all the novitrixg nours, are.must he taken that the Caterpillar's are not struck by a "sudden change of temperature ;" therefore, to the windows and all other openings mast be given the 
SECO AGE.

proper attention. Neither must they feel sudden shocks; bener care must be taken in movings. "with more consideration in th. nuoulting hours", the swingers on wbich they are layiug.

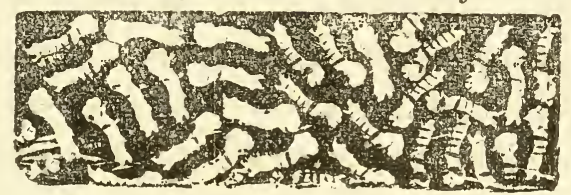

Catcrpillars should not be kept more crowded than they are seen. in the above engraving.

Bindtine issuing from the egos are a little smaller than the Cat. "rpillars of first cut. In all this agre no more than twelve pound: of leaves are needed. For food wanted daily and in each age. ses table pablished in this Directory.

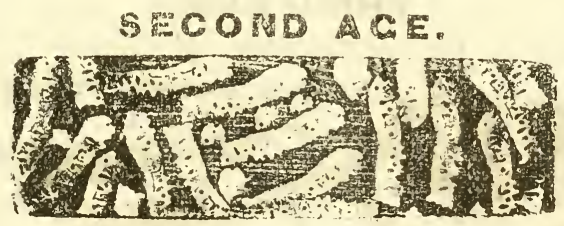

One or two hours after Caterpollars are moulted, thoy begin to look for food, which mist be given to them on the small-sized per. forated straw papper (page 18) in order to change them. (Ses. CHANGING).

Caterpillars issued from one ounce of eggs will occupy at this age from twolve to : yterul shetes of stray baper, according te the liumber of them lunglit safuly to this time. They go througi this second acre in lass tirue than in the former-that is, in five dirys. Wrhen just monlied the sime their heads are about thren-fold lareger than before: an : whitish ; their body has a dark rray color which continually bre seleurer nutil it takes an ash. colond bue and a little pollomi At this time two litte curves 
$\because H: R: \therefore:$.

ines are perceived on their buck, as $=$; hesides, their body's iongth yncreases [if they are healthy] to the size represented in the above unglaving, and their weight is almost six tince greater than that of their tirst age. On the third day they must be changed again and situated on from -ixteen to twenty-four sheets of paper. When they rest for the serond moult they are amost transparent and look us in the first ent here below. Food about inirty.eight poinds. See table).

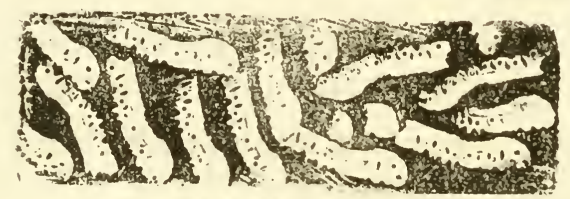

\section{THIRD ACE.}

The medium size of Caterpillars are now thus :

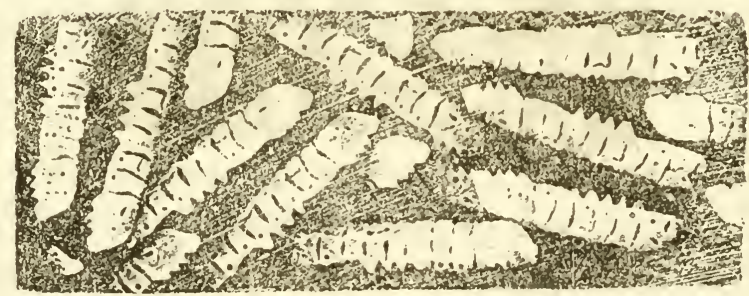

This age lasts nearly seven days. The Caterpillars must be changed, as has been shown for the previous age. As soon as they begin to look for food they are ehanged and situated on from wwenty-four to thirty-six sheets of straw palper. After the fourth daty they are changed again and put on fom thirty-six to fifty heets of paper. When just moulted the second time they seem pearl-colored-sone of them looking speckled. At this stage of their life they always become more clear and white; they also inrease twice as large and four times as heary, and when they rest. 


\section{FOURTHAGE.}

to molt the third time, they appear as in the next ent:

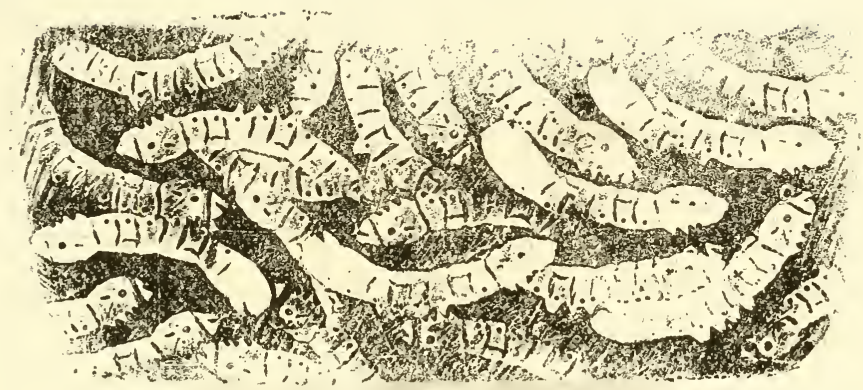

\section{A BES}

The caterpillars are kept amost always too crowded, and is rhanging them many of them are thrown away with the litters. The leaves are kept too much piled up, and when gathered arw prounded into the bags or baskets. The leaves will ferment or at lasi sueat, which is enough to ruin the best party of Caterpillars.

\section{FOURTH ACE.}

(Rnies given in the different AGEs of Silk-Caterpillars are meant for the number of (aterpillars issuing from one ounce of eggs.)

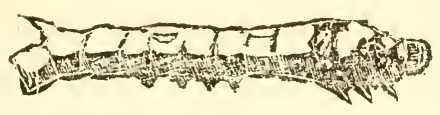

(aterpillars go through this age in seven or eight days. Afte: having just monled the thind time (as well as in all their other monlts) they appea: for a few hours rather frible, being stil: until whon their very dolicate skin, and particualy their snoots, ne grown firm; afier hwing bees in contat with the air, then they arequire strength. look for food, lose their light terra cotte color, which they had after the moult and become more white. daily. Sow, it an be very well pereeived if they have been rat- 


$$
\text { F. FTHAGE. }
$$

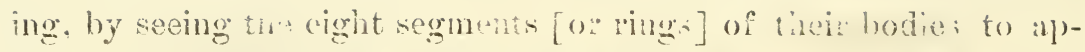
pear of a greensh hue. At this time of their lif they waw ans large as the al) engraving, which has been tiken after nature. When silk enrowers find their Caterpillats about as barge as those herein slietched [unless they are bivoltines] they can hope for a grood suecess, a: well ats when the Cuterpillaw: monlt, resting alout in theosame posion as the foliowing:

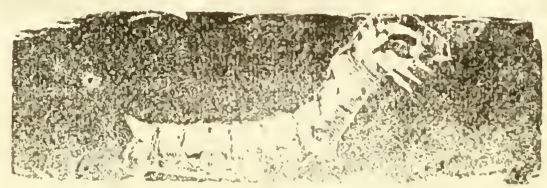

Feed as in the Table. After moulling the fourth time, and when they move the forepart of the body in securch of leaves, they must ieceive them on large perforated parer and bo rhanged. This lime [if a great many of them have been reared safely] they must oeculy. about eighty sheets of straw paper or fromi six to eight shelves. fix3 feet. On the fourth day they must be changed again, and put on from 80 to 120 sheets- eight to twelve shelves. Tho Gaterpillans are not injuried by cold ueather'; they only need good food. plenty of pure air and cleanliness; that is, they must never lay on old litters, and what is worse, on fermented litters. To avoid odoms. 'atte: "change" in the carly morning hours. Do not give too many leaves at once. [Soe Table.] But if the woather is cold, they do not est so much; whilst they will eat more than is calculated if it is very warm, and the latter ane is better beraus they become ripe sooner.

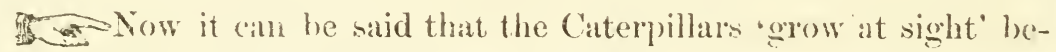
ause two days after they have gone through the size of above engraring, they will increease in body, and appetite 'considerably' : and 


$$
\text { FIFTHAGE. }
$$

now is the time to use better carcs than ever. Within ten or twelve days, will come either the produce or the disapointment-which will ba felt mo:? of course, by those who expecting to make plenty of momey ontla!'.l ["uneco:tomically and witho!t experience"] a little 1(x) much anit.il to stant with.

\section{FBTEACD.}

At this age the Cate:pillars grow in weight six times more than the procoding one, and reach the size of this cut:

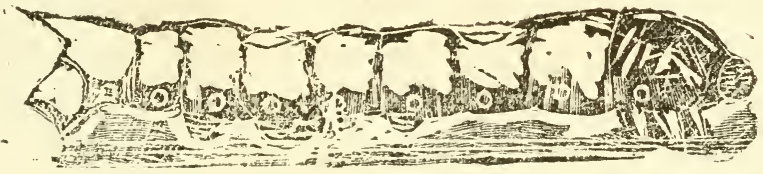

In the first two days, after having them chenged and situated on from twelve to fourtcen lattice-like shelves, they must be fed with discretio:s, but after that time they mat be covered with leaves one o: two inches dee ', sir times in twenty-four hours, and if they linish them in less than half of an hour, they must receive more: in short, they must at continnonsly ; if otherwise, they wili spin: had cocoons. If the seasen is very warm, the leaves must be giver; in less quantity and oftener. Total amount of leaves eaten by nearly 39,000 Caterpillars is about 1,300 pound:. At least every other day the Catcrillars must be chared in this age. If many Calerpillars have not been lost in previous ages, and if the weather is very damp, it is better to situac tham in more than twenty-foir shelves, as shown in the table. To make it casy change : 10 Caterpillans at four different times of the day, a part each time. When they ane changed on the serenth day of this age, the sicetw of straw paper must no: be loppol on the shelves (as it 
ज. $\mathrm{THA}$ A $\therefore$

must have bes some before), but must be situated there one inch

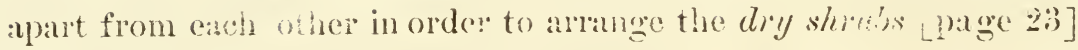
among them.

Should the 'litters' appear very damp, and if it be impossible to change, it is u w ful to sprinkle them will rivmbled stray.

Wroe to the caterpillar breeders, now, if they shut up windows, doors or any air-hole; if they do, they jeornardize their incoming silk crop. $W^{r}$ spoke of this already. If it is too hot, swerey the outfit a while. If the sun's rays strike the Caterpillars, overshadow them with paper, linen, ete., and if it is danny, wait, but do not shut the openings of the coconory ; remember this, and in a few days you will be rewarded for the pains taken in the short forty days (or less) of cares.

* * The above paragraph is limited only when a wind-storm is aging, in which ase small apertures will produce a little draft, which ran supply all the needed air.

To avoid odors carry the litters a littroff, let them dry in the sun, and they will also be a good winter fodder for your live stock.

Caterpillars after their fourth moult, which ean last even two days or more, (if the temperature is low and if they are in good health) when undressed of their former skin, have a terra cota color ; next to this they show from their tail up, a tramsparent yellow rosy tinge, which advances onward toward the middle of the body, until it hecomes all of the same appearence-rery unch like * piece of amber examined through the bight.

If the Caterpillars are of the white-cocoon-producing-breed they do not appear to be of a yellow rosy bue, but they are pellucid. nevertheless.

When the Caterpillars appear so they are near to become ripe for spiming their silk-shlerouds (cocoons) and when after a few hours 


\section{FIFIH}

hey become so, they climb over the leaves, without eating them, and begin to ramble,-even wandering from the shelves if the silkcrower has not provided for them the dry shrubs, ahout which is rpoken on page 23. How to arrange, the said shrubs will be written in this work, in apposite article, hereafter. When the Caterpiliar: have found a place where to spin their silken cells, they promptly climb on them, taking this posture:

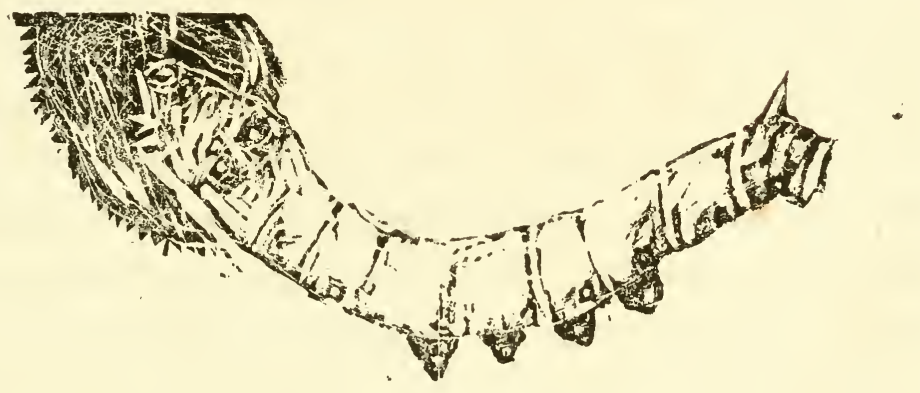

Rsmerks:-Now in the above sketch is seen a Caterpillar which, a!though safely arrived to the silk-producing stage of its life, yet cannot be of any protit to the breader because it was not provided with the required 'shrubery'. The most urcful insect, in this casc, is wasting away its silky substance-on a piece of mulhery-leaf, vainly tryiug to fasten the first webs in order to envalon itself in a cocoon.

Here, now it seam: u icful to point out that noither "little cormucopias (made of old news papers) nor the *PUT THE works To spra In THE FOLDS OF a DRess* [as published in a weekly-paper] have any thing to do with the rearing of even a few thousand of larva: the 'folds and the cones' might be used by students and curiosity- 


\section{ERRORS IN THIS AGE.}

-echers, and not by silk-growers. Hooden frames with cells one inch square and (ne deep) are also used, but they are expensive and...and hruby-plants, auswering the same purpose, are so plentiful in America, and so cheap :

\section{ERRORS IN THIS AGE.}

Not gring enough leaves to the Catepillars, or giving to them tender leaves are mistakes that will put in jeopardy the presamably pproaching produce. Want of air and 'changing' are also errors to be avoided. Inattension of mice, poultry, winged insects, cats, is also faulty -if ants invade the 'Swingers', they can be stopped by putting some 'raw-cottor' around and at the top of the lines of the Swingers. When the shmbs are situated too crowdy it is atiso against the larve, which in this case camot be supplied with air and will he suffocated in a short time.

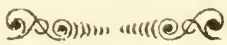




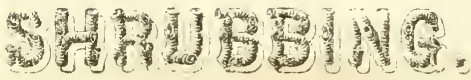

Lomb before the Caterpillar have reached this stage of their life silk-ginwers must hive prepared the dry hrush-wood, turnipstalks, heath or hay, etc., ete.

Now four of tive days before the Caterpillars are ripe, aily of the above brush mut commence to be arranged on the shelves. This is dons as follows: After the fine stems of some of the shrubluery have been reared will leaves, secds, tops, ete., they are placed on the spares now left between each straw puper, and so the first ripe Cat(apillas, which would like to wander fron the paper in search of: nook for sponsing, find a ready suitable place and there they haild? thrir silken howse-fastening on some of the little twige abd stems, a web-like-net which they make gradually smaller. long-shaped, roand and thicker, until when they have enveloped themselves in
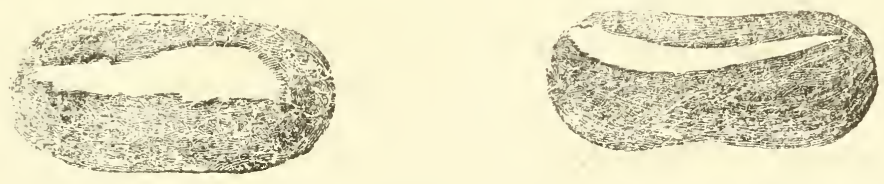

their silken shrouds, nsually called cocoons. On the ahove fine stems of brush-wond others are added with care and when the num-

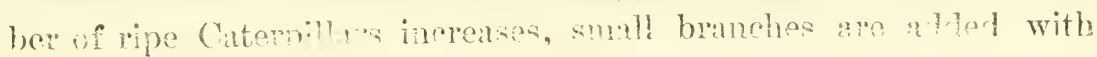


$S H R U B+N G$.

the inferior yart on the shelf and the superior one, opened like a fin, laying on the shelf above as in this cut:

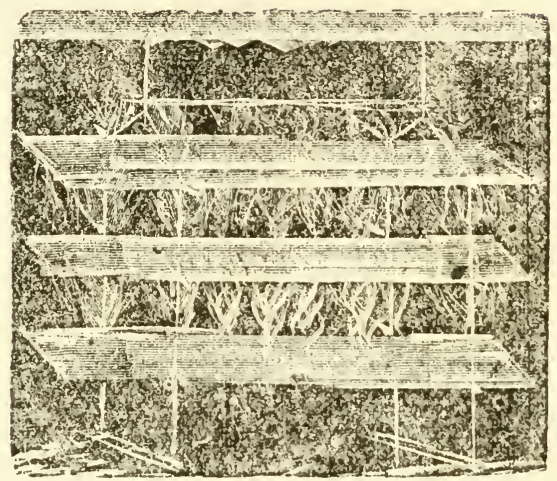

If neithre the brashwood nor heath, ete., is on hand. shrubhyplants of any kind will suit, provided that they are well diy branchy without leaves, thorns or little twigs, apt to mix up with the outside weh (fioss silk), and particularly not very (rowdy or thick in order that the air may circulate freely also for Caterpillars ripening later. This brush must be high enough to fit hetween two shreves and form an arch under the upper one. If laay is ased it must be tied up very loose with twine and made to suit the sime purpose. When almost all the Caterpillars have climbed on the shubs, some well seasoned leaves (not dry because they will crumble) of oak tree must be added among those which ramble around without going to work. The shrubs, by reason of their 


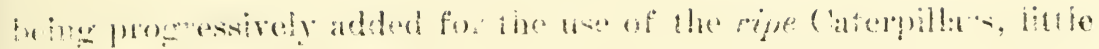

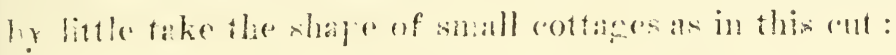

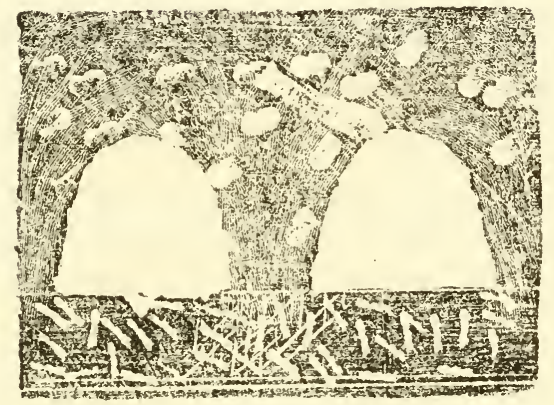

Care muge be taken that the side hash do not come outsele of

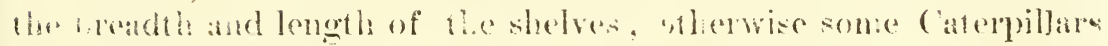

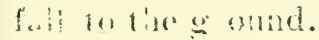

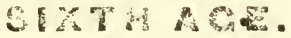

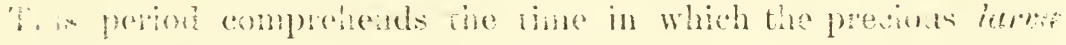

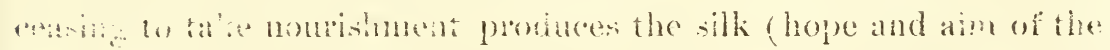

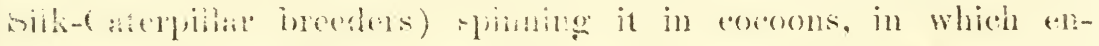

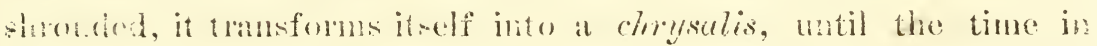

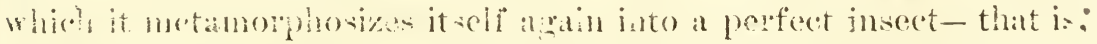
mito a biatrenty.

When the caterpillar: hegin to become ripe, that is, become

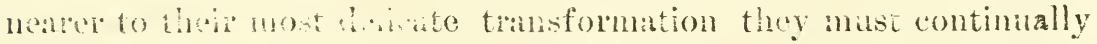
bathe in pure air, hut mow as woll as when they moult, they muat not foul sudden changes of temperature. Keither cold nor warn wather. humts wel fel, not overerowded, often changed and wellaind caterpillars; they mat bo protected only from sudde: 
$\therefore: X \% 4$ A RF.

(hanges of temperature. When too warm do not admit too many pople in the (cosonery, and in rainy woather do not admit damp' objects, but whilst a sudden eolt weather or a bad wind disturb and alrest the respluation of the caterpliars, the want of air, if doors and windows are kept clored, will choke a laroc swarm of Catcpillars in a single night.

At thin age a 200 long abstinnene mar also be aganst the Caterpillaw, thorefore if leaves should bis wet, they must be dried antiticially (we sad how in the first part) but the (aterpillars must not be in need of them a single hosm.

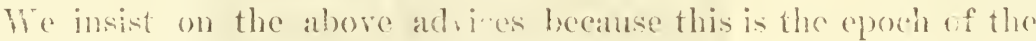
disappointment for those who bare reared the Caterpithas withouth the d!ue altention.

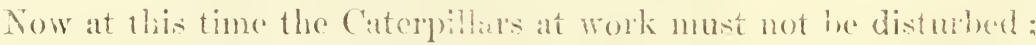

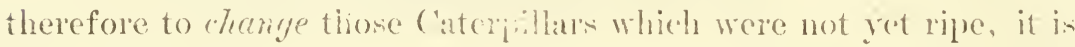
necessaly to feed them with whoots, and when they hare chimbed on them ther wan be remorod an another shelf; the litters then ane gently sweyt on the dast pan and carlied out. If some ripe (anterpillars do not go to the shrubs they can be mored with cane a litule :owards and near them : when orly a few wanderers are left among the cottages, it is hetter to remore them to another shelf with reaciy "nade shaublocy.

As a rule, Caterpillars climbing fieely produce the best rocoms : when sueh ones. aftein (limhing (mupty themselves of a few drops of (lear water, they foretcil an excellent silk prodnce. For nentrese" sake, sprink? now a light laver of crumpled staw upou the straw litters.

Two and rven three days after the first Caterpillars climbed (if they are rery healthy and the temperature is at from so to 8.5 de- 
SIL KMGATHER,NG

arefs) almost all of them will have climbed on the shrubs, those excopted which must be pat by themselves, as explaned above.

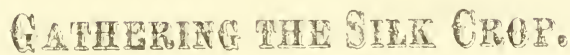

T'irea days after the feu unvipe Caterpillars have been romoved to at an eial shelf (on in difforent woris: thres days after the greatest number of Caterpillan have enveluped thonsolves in their silkenshroad) the (istmensig must be aceomplished, and it it is done much later, silk-growers rin the rikg to spoil the crop, for reasons piren hereafter.

This notot delightful, casy, and chaming oceupation lasts, by no manns, a short time-wixn about 20.000 cocoons must be colecent. Then, in order 10 do soon, as is required, it is at treat and a commodity to invite sone fanty frends who willingly will neli, in this last duty.

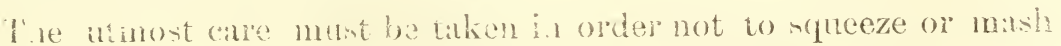
the rocoons. Thene;-

The shrabs, haen wih the ahamg pecious silken shroudi, placed upoin the bottom shelf of a "Singer" must be taken down first, and he situated on a clean place; then all the others porgessirely. After this has been done, the cocoons must be gathered from each shru'; and sproak, about three inches decp in a dry place-say on one or two well cleaned shelves covered with new puper.

Now, whilst the coeoons are collected, they must be, strictly, assonted "haking away the soiled, the shapeless, al! the donble-cocoons, (i. e. those fow very lange and rery hard, containing two 


\section{PRESERYING COCOONS.}

arye) and all the imperfect ones, which are those not being like he larget number. The size, if the cocon is not otherwise worthess and if the Caterpilal's were well fed, loes not depreciate very nuch the (rol). On this areount silk-growers, for their own interest should not mix strined cocoons with the fine ones, if thy dos the vhole lot will he depreciated.

\section{PRESERYAE TH COCOONR:}

At this stage all the cares of the Silk -erower should be orer and my the dispesal of the erop stondid he looked after. Yot, to maks? this bonk complete, we give lixe the next oprentom perform d on the new, or fresh, coeoons.

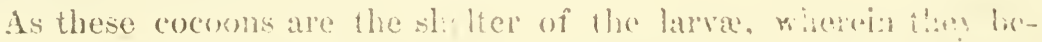
come a periect inseret [that is, a buttorly] so. When the larva bave changed their forms, for the fast tome, the latter lour the iomer and come to the light acuin, thus:
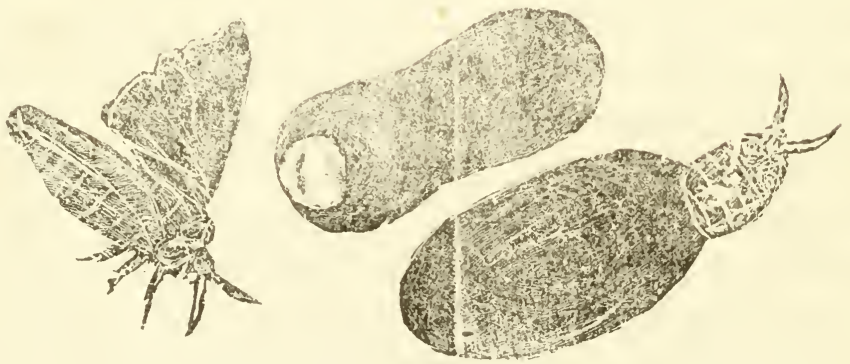

Now the larve becone buterflies within 10 or 20 duys afrex they have enclosed themselves into the silk, the higher the temperature 


\section{PIESLRVING COCOONS.}

the sooner they transform; and after they are out of the cocoons they reproduce (see sarnobucrion), but their shrouds after having been pierced cannot be reeled-i. c. wound off for making first elass sitk-igond:. Then, in oider to make the cocoons good for this operation, the coming out of the butterities mast be prevented.

This is done, efiecturlly and whileut spoiling the prodece, first by choking the shrouded insects with steam, and then ly gradually drving their remains in the eocoons.

Wo stifie, or choke, it is needed an apparatus wherein the cocoons are spread in different layers two or three inches high: then stem is tumed into this arright apramatus, for about tiftecn minutes, after that. hot-air is substituted in the room, and in doing so tho enclosed in:eets becone lifeless and dry, and the silky-shrouds ("an ho kent inatet a rery long time.

Xow the stifling and drying-roo!n is attached always to those establishments which buy the raw-slk-i. e. fiesh cocoons: therefore it is not $\{0$ be recommended to the Silk-growers to attempt the stifing of the larro-particulary because in doing it ;-

First; steamed cocoons, if not gently and progressively dryed up, will mould, and becoming spotted will greatly depreciate: and second, they camot bo sold as soon as gathered, becuuse if their builders are choked they must, also, be dryed to accertain the weight of the silk, and to prevent the moulding of the silk.

At any rate; if in the past it has been recommended to the Silkgrowers to "stifle the cocoms" (?) it bas been because the buyrars 
PRESERVING COCOONS.

fid not have accomodations for doing it, oi did not know how to do so, or did not want the risk. But when this produce takes such a short time to be raised, it is a pity to jeopardize it with operations which do not belong strictly to the grower : besides it is too bad that the industrious persons who work in early Spring camot inake any money (if any!) until late in Autumn-whilst the strock is on hand and must be kept safely watehed and stored!

About the reeling' of the rocoons, by the silk-growers, it hits i cen written elough on the fourteenth page.

Finally; those who raise silk to get a silk-dress, shomld convider that it is easier surer and quicker to buy one with the money med in a short time, with the raised raw-silk, than by trying to make one, or to make cheap handkerchiefs, with it.

We found the new food for the Silk-Caterpillar. and wo give the suggestions which make silk-culture a real possibility here.

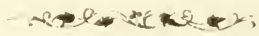




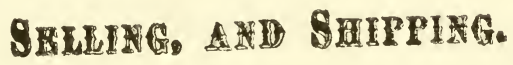

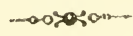

The best way, nay the ouly way, to sell the cocoons is to send them to the reeling-mill.

The firsh cocoons, in order that they may not be crushed and spoiled, should be laid in tight boxes having partitions each sis inches.

They must be sent by Express, orly.

It is better to send to the silk-reeling-mill only the perfect cocoons-the imperfect ones being very few and commanding : very low price. They might be good for fancy home consumption but if they are sent to the market with the good ones they must be laid in one of the partitions by themselves.

The waste cocoons, of a succssful rearing, will, scarcely, averag two lhs. in one hundred pounds.

Never fill and ship two boxes when you can make one; if no: 
SELLING, AND SHIPTING

Wxpress charges will be double! And if you can join your silkcrop with the Silk-growers of your neighorood, do it and -hip in one box with two or more divisions.

* Doal always with a "truthful and pratical silligrowing-firm which at the proper time will answer fiee of charge, for the advancenent of silk-Culture, for the destruction of foreign monop)oly, for the welfare of industrious willing youtl and old age, will ansmer all yuestions pertanis of to Silk-llubandry, with gladness: But, be sure to aroid the sik-hrokers. (real ol otherwise), hacause they buy only dry creoons and on commission: which rally means that they do not huy foom you, but that they will sell

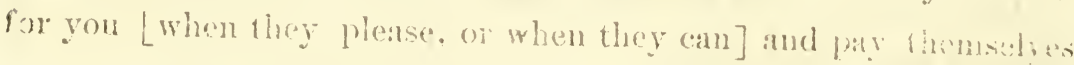
first the "fearful biokers-fees".

This last part is uot ahout silh-Culture, indecd, hut is is of such iuportane for the suceess of it that wo conclude with the poet:

"A WORD TO THE WIAF 13 SUFFICIFNT!", 
-BUTTERFLIES, FECINDATION, EGGS.-

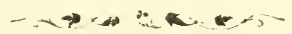

\section{SEVENTH ACE.}

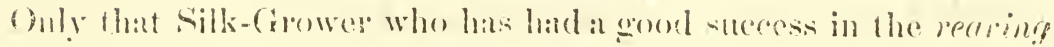

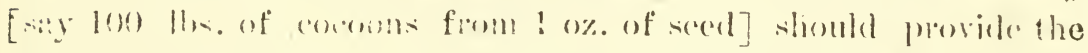

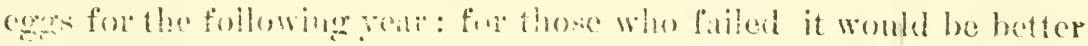

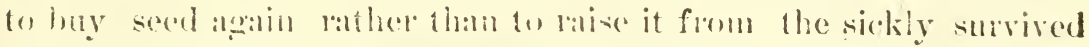
latre and huttorflies.

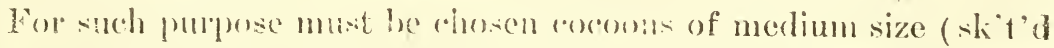

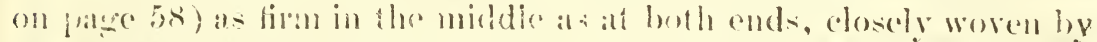

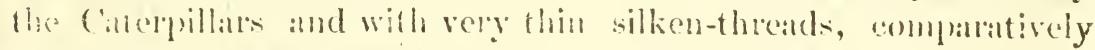
beary and perfecely tinisherl.

The "oreone must be examined one hy one, and must be gently shaken in order to hear thr light thad catued by the pupu [called alon clengserlis on curelide] striking the walls of the encoons, when sinken; but the shrouds that do not give any sound, after being shook, mut be dispariged, hecante their eheyalis is worthless.

bouble rocons, (see patge 57.) thuse the least soiled, the shapeless and those ston tight' in the middle must be aloo disreganded.

It is well to raine clouble the amount of seed wanted the next year lerenuse if the first incubation farls, by any unforeseen cirumstance, it ean be repeated by uing the rest of the seed which hat not been put all at once in the hatehing romolia hesides it is alway's well to intiate some new persons into silk-Culture, and when a few exgs are on hand they will turn useful for any mentioned purposes.

But it is the sille that is wanted and... well the grower will follow sugrestions given on page 13, and be repaid for his cures; otherwise his success will come to naught !

As a rute, from one 1h. of selected cocoons (nearly 300) cais bo 63 
obtained one ounce of perfect seed-porhaps one fourth more than the above amount can be obtained, bat it is better to be strictly rigorons in the selection of the parent, as here beiow, than to be careless, or 'stingy', and so prepare umpromining soed for the next rearing. The heariest shroud rall produce a fenale butterily, the lightast a male one.

The chosen rowoons, first, mest be thomughly plucked of the outside weh, or loose silk, and then matst be latd one after anobine on the new paper of a well clamed 'airy-sheif' at a teinperature of fo to so-the higher the temperature the soner the cimpsalis be comes a butterfly, hat a medium temperatume suits cvel lietein, in Iarvat, chrysalss, and butterhies.

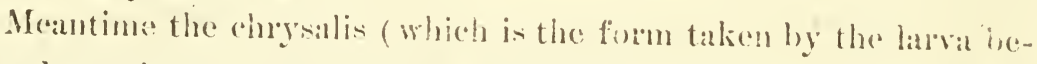
forr becoming a winged insect) fo:ms itself inside of its shrond. it shrink from the previous inseret into an oblong and oral forn: and and its cprdermis takes a wolden hue in the tirst day of its natamorpho-

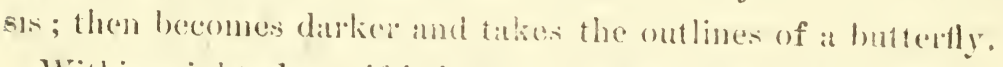

Within eight dats, if it is very wams, and tifteen days, if ahe temperature is medium, the onthines become perfece parts and the chrysalis soffoning onc end of its shroud emeroges from it.

The fombix mago, athough is endowed with perfect wings, does

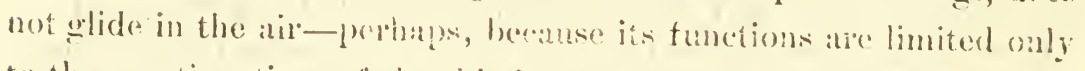
to the continuation of the kind, atsd wot to the self sontenande: butterflies, do not eat, therefore they (io) not watider !

It sumpise only, or thereabout, the hutiterfles conc forth.

At tirst, they have damp and imperfect wings, but in a few minutes the wings take thei: nomml appeadance which is:-

Healthy femaie butterflies are larger than the males, rather heary for heir size, on which areount they are almost stationary : their wings are of a pear-white eandor slightly shaded and are always 
kept horizontally stretched, like in the following life-size figure:

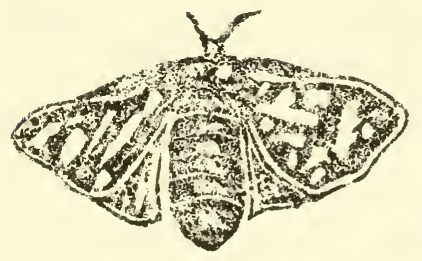

the wings and the other parts of the body are evenly covered with a very light down.

Unhealthy females have either ashy or a chestnut color, some times being dotted with a fow almost unperceivahle black spots on: ilie white: others have an execptionally enlarged belly, and others : are crippled: more about these ailom.

Healthy males, besides of being distingui-hed by their smaller size and same white color, are lively and with open and shaking wings ["called onward by desire"] whirl around their more steady compansons. The wings of the male butterfy, when at rest, are diagonally ifted up from his bo!ly. The males are also particularIy distinguished by having wider and longer feelers.

See page $5 x$ for drawing of male butterfly.

Unliealthy males present the same characteristics of the unhealthy females, though more of the former might be almost wingless.

Having described so far, it is now a short work to direct how to make the "choice of the tittest" for the Reproduction. Thence:

A little after Sumrise the reproduction-room is visited and the butterflies already united are gently. collected, rouple by eouples 


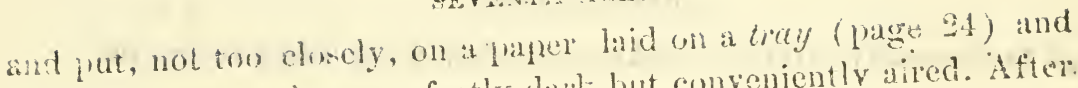
carried in a roon kept perfecty dark hut conveniently aired. After. that the coupled interties have hevil removed, all the single ones are taken and put together, outside of the encosis on the sholf: then when new eouples are seen among them they, the coaples, are brought aloo in the datis room.

Now, at the anplus having been earred away. it happeas that either some malos of a few females have been left single, for want of a mate, in the reproduction arom. Then if the formel ate mateless they mut be preared, brease the next day there might be at majority of females, and if the latter are mateless they alon must be kent, and ata be mated, aftere a couple of homes, with a mate which has already becen in the datis room. But to preserve the male

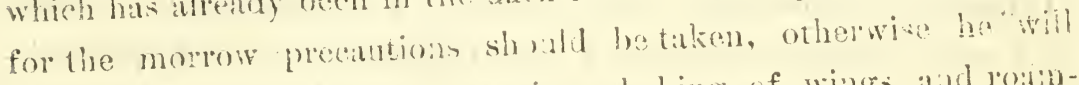
fatigue himself with his unceasing shaking of wing and loban-

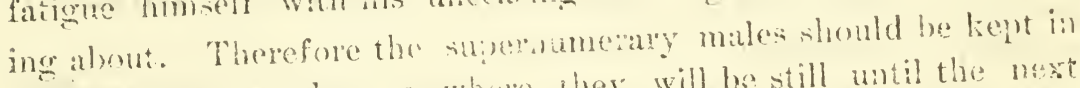
small boxes, one by ous, where lhey will bo still watil the nest day, when eomestheri tum.

Before proceding: now all the ',utterties pmerged fom the eo-

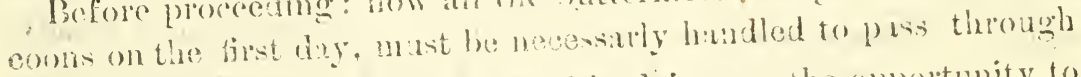
the above deseribed attentions, and in doing so the opyortunity to make the choive is afformed. Thewefore, now, rrive away to the poultry all reddish, gellowish, ashy-olopedbutterities; awa all tho black and black-spotted ona ; axay all the dropsical ones, that is, those with a swollen belly : away these with one wing and the wingyess : aw: to the fowls all those without feeless or with one feol-

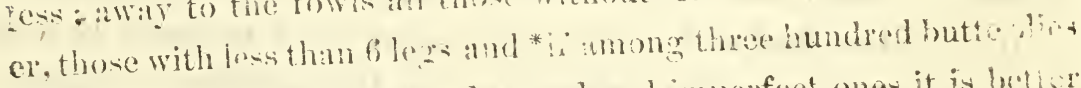
are found more than thirty discand and amperfeet ones it is lortion to do amay with all of then and bay new seed rather than compro-

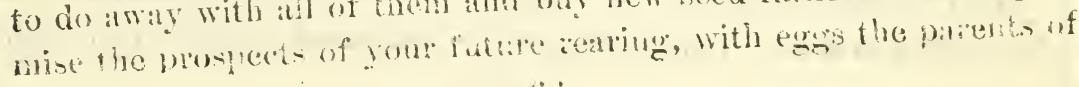


which were imporfect, even only, ten per went.

For casiness and ecomony sakr, it has been direrted herein that

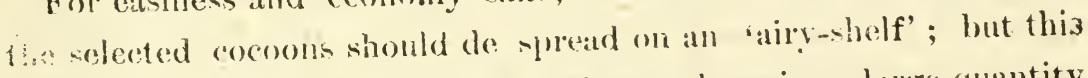
given hint is particularly good for those who raise a large quantity of 'industrial seed, for sale or for distribution. But, Silk-Growers who provide for thenselves only onc or two ounces of egres, can uke a small iable, or soncting liko--eppecially winen they prepare the inclined surfice for the reception of the laying buttertlies, as below.

This is accomplished by stretching one or two pieces of undressed nulin (which, for the bath, [1.41] is bette: than pitper) on one or two small trays, like those of page 24 , and hung like a frame from the wall-but uplifted with a little prol ander the lower part and not slanting, like framer, from the top. These frames will answer very well to contain each from 90 to 100 laying butterflies which will deposic about 15 thous:und egas.

Some butterflies will rentan united, even, longer than a day, and ret the cags have been found, an fruitful an when their parents were coupled, only, one half of :n howr... Let them alone anyliow ?

As soon as the females quit the males they mast be watched until when they have delivered themselves, agam, of some reddish liquid, then they must be taken, anew. gently by the wings, and piaced (in the prepared muslin.

The butterflics will rject yet some of their supertlous humors whilv they are laying the eggs ; as this moist ure would endanger the healthine-s of the seed. it must he prevented. This is accomplished hy inclining the trays-hoiding the linen, as much as possible and by situaling the butterflies from the top, first, asd not too (1)-ely lo each other.

If the choire of the cocoons was made from a party that dial not

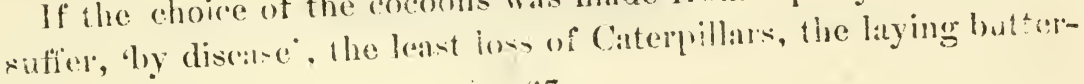


flien ran be allowed to lay all the iv egon, which will be just at good as those laid earlier; but when a few: Caterpillats died hefore building their shrouds, then the butterflies mast be allowed to lay for about 28 hours only-the eges laid after lhat time containing rather unhealthy life, as it has been found by diligent ohservations.

After the batterflies have done their dutics they are abandoned.

"Industrial seed" is poocured as above: "couluhar secd" is pre-

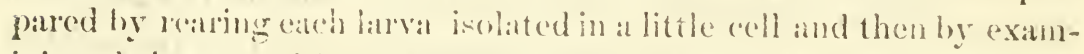
ining their egy- with powerfull microsectes ete. As only few trunt sind an follow this method, we do not describe it at lenght.

\section{raxack \\ PRESERVTION (OF SELI)}

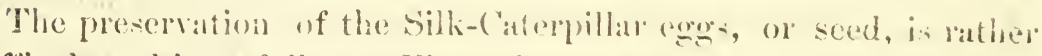
diffient and is as follows. First, they moth be protected fiem mires and insects, which is done by suspending the muslin whereon they were stuek, from a coiling, and hy risiting them ofien. Second: they must be kept from hatching hefore the leares which they aat have sprung forth. The eges of the 'anmuls' cambet hateh hefore having realehed the eignth month of their age, hecatue the embyo of the little insect will not be formed hefore that time--a few hunded of them hatehing makh soomer, hevertheless. Now as the egoss, in this comntry are obtained in the latter part of June so it appears that they would he ready to hatch in Mareh. when there

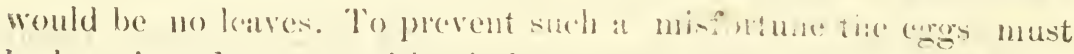
he kept in a dry rom with windows at the north. Air should circulate freely in the room, also cold, int erenly; therefore in a coold wave" or wind-storm and at night half shat the windows.

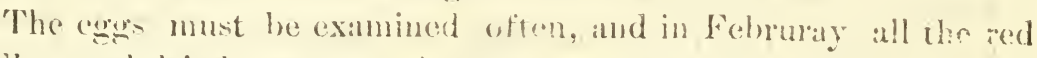
yellow and dried one must be cratad from the lines. [see p. a. ] 


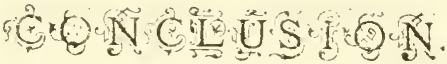

The directions given to the presont in this book are all what is wanted [in a positive way] to know, in order to rear silk-caterpillan economically and successfu'ly. We did not give speculatice. informations because they are not necessary to 'practical' silk-growcrs, hit are only practiced by -exporimenters'. Therefore we conclude this mIser pant wite the following encourang words:

Those silk-growers who were scald at given positive and exigent teachings mat now reflect on the great warning given by Mother Nature, whoh provides with many egs cerain species of beings (as to say the moth of the Silk-Caterpillars, which lay from 450 to 500 engs) because their existence is rery diffeult to be preserved. Thence the polability to protect them from diceases can disappear for every atmospherical advermity or for neglects and mistakex made in their rearing. Severtheless, it nust not be supposed that the Caterpillars are withoat possibilities of living: in fact, it is almost imposible to destroy their short existence, when they enjoy it finely : and althoneh they perish somotimes whon kept raitiro, yet it can be sad that they are rather killed by their breeders than destroyed by nature.

Xow the following information mingt be sum jont to a conage all per. ons engaged in Silk-Culture;-

1. anterpiliars can live at a low temperature in whis they 
CUNCLUS:ON.

remain in a comatose condition, and do not eat eren for weeks.

2. Thoy can stand to a high temperature, when they devour much food and become ripe in a shorter time.

3. They cannot be drowned before hoving been kept at least three hours in the water.

4. The rain does not hurt them, and when it rains, they do not aat before the wet is evaporated.

3. Neither gas affects them ror sulphuric funigations.

14.

Before coming to the end, this Silk-Culture Directory wishes to ary that it is better to take prung Caterpillars from *aperienced ieading breeders*, than to buy cven perfect eggs becaust' ; me single hatching-room fitted out and out, is capable to furnish in spring, oven, 1,000 families with young Silk-Caterililars: bat s." 1 namber of families require 1,000 hatching-rooms, completely antitied, and 1,000 experienced persons when they will hatch ergs themselves sorogressively, and after that they have been properly preserved from the time they were laid te, when they are put into incubation.

This last sugegestion goes to show that the leading-firm, which distributes [on nominal and easy conditions] the principal stock to wtart well Silk-C'ulture, and buges the prorluce for Radr cash, may incur a loss, (if it does not know the business, or if the scason is unfavorable) but not the silk-giowers at large.

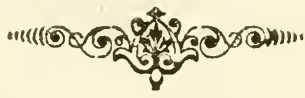




\section{APPENDTX.}

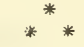

The directions regarding shelves made with "building paper", directions given on pages 17 and 19, should not be understood atranst the foundamendal principles of this system. In fact; the thick paper, being less porous than lumber, shoyld be perforated in order to be healthy, and if it is not so it will do more harm to the Caterpillars than any lumber shelf, because it will be a worse conductor" of air.

$$
{ }^{*} 0^{*}
$$

There is enough of proof to hold that the Caterpillars are not. destroyed by imaginary ravenous motes and ribrioins [See II part], nevertheless we cannot be to stringent in akking, for good success, that the utmost cleanliness should be inforced in rearing the Caterpilliars.

For such purpose in the Old World. now that the Saterpillars are fearfully ravaged by diseases and untimely deaths, they use in 
washing and divinfecting the old rooms the following dingess soda, chlorate of lime, suphur, saltpeter, mipharic acid, se:t-silt, oxyd of minganese, lime otc..

Now the lime is a mechanical contrivande ured as white-washing

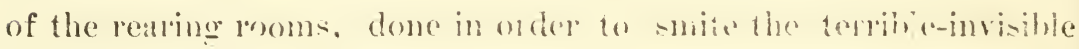

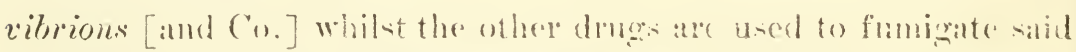
rooms before beginning the rearing, also to biast the moneiles, known, by supposition', fo be hovering all around the room wat-

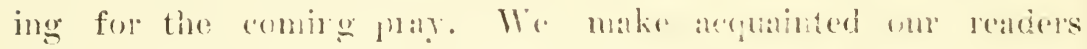
with such haypentuge, and now we will also write down one of

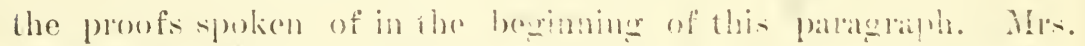

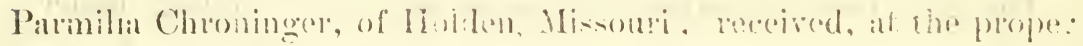

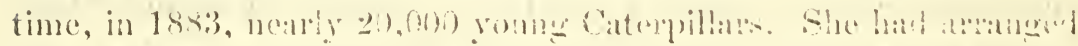

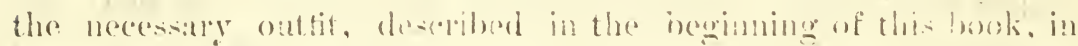

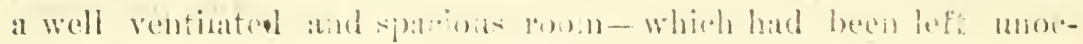

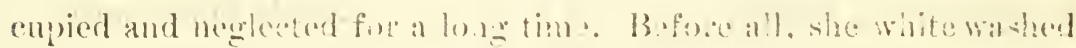

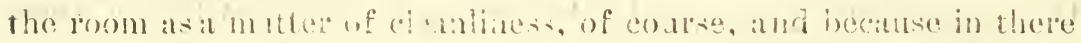

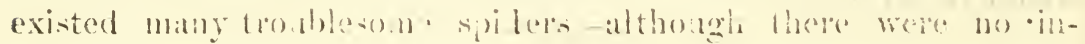

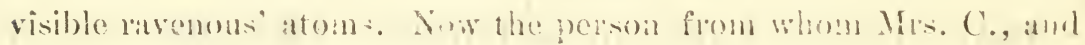

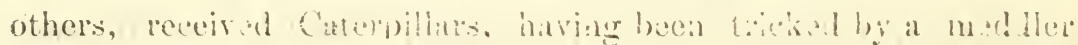

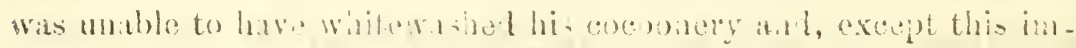
portant precaution, he noed whist he reared, at and even mone

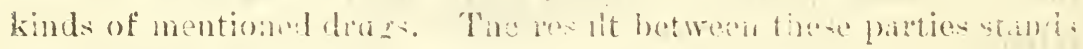

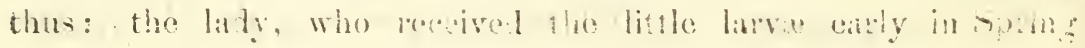

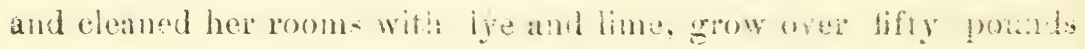




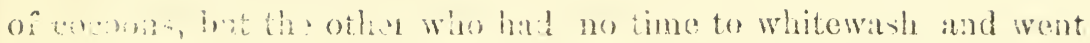

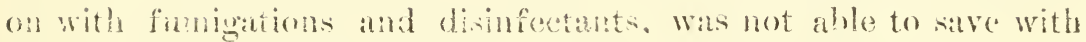

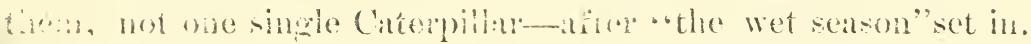

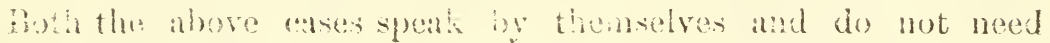
ai'l comblent .

fll some states tha loaves are lon full of water because the

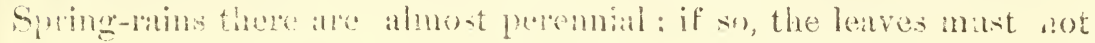

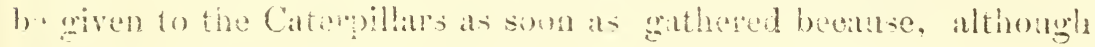
they do not sexun wet get, they an exwessively damp: thence the

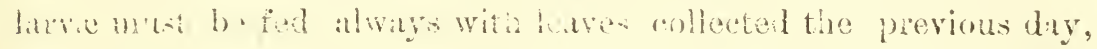

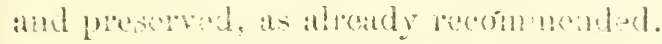

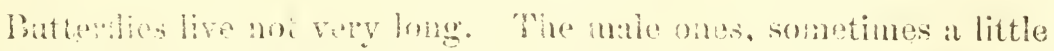

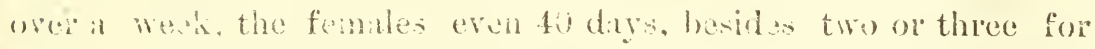
laying-ine somer they die the kes howe can be kept in the vitality of their enter.

When the firoe [that is, the boath-Eatst wind] blows, the have mu-t he protered with the ntmost care becalse it has been ex-

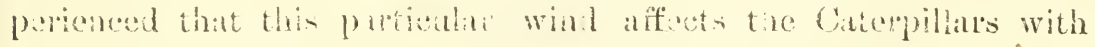

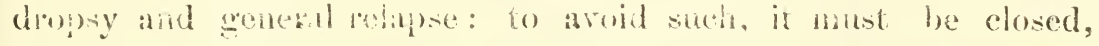
for the time boing, resy aperture at the s. E.; and when there are many opentages in the coenonery it is better to chose, or leave a couple of inches open, those wherefon any stong wind enters and aiters the temperature. It is well known, in this case, how 


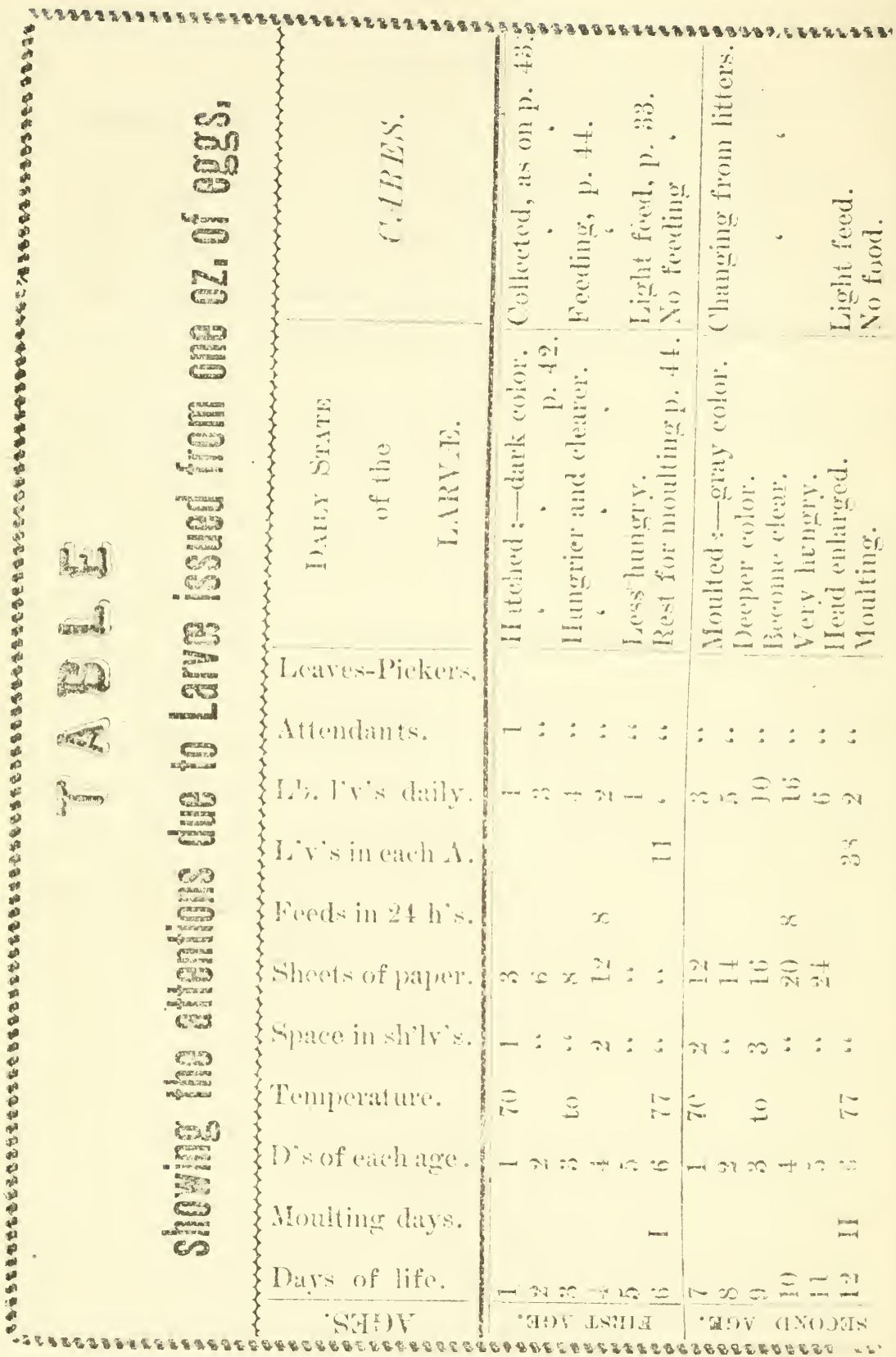





\section{SECOND PART.}

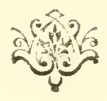

Hôn

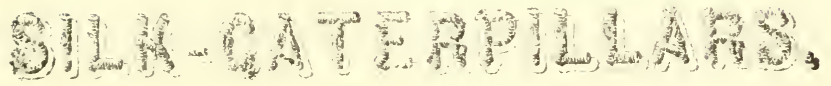

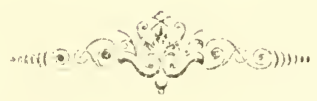





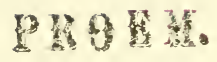

"Here all suppicion needs must be abandoned. All cowardice nust, need ise here extinet."

Lomgfellom.

It is weil known that all organized beings wo through wertain ahbumal prouls, dumg their lives, which are called diseases.

Inlustrial harre, or Silk Caterpilars, are thenee aho subject to disorders in the ordined parts of their body : but, owny to the extreme small size (which among domestiented animals is only next to the boncy-bee), to the present, they have been kept out of the eares of the medical scionce, and at the same time being so valuable have fallen $m$ the researches of speculative savants.

These embroiled in deep suppositions have pretended to suppress death giving out that a parasitical-microscopical (!) life was the catase of the most destructive laveres-and the interested people. like a drowning peron tha mensps at a straw, in order to rear 
their larve, acecpted the theory and paid...for some years to the ipeculative school.

Then the theory based on microseopic observation gave way to modern physic; therefore now the insects are studied by patolugy and biology lather than by un̈̈omoled parassitelogry.

To be hicf and avoid to employ much space for the mioros copie controversy, we will give here below illustations with tha hippotetial points shown by the originators of the microscopre finds-reserving to us the space for exhibiting the intianatory and phlermatic character of the more fatal distcumers.

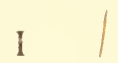

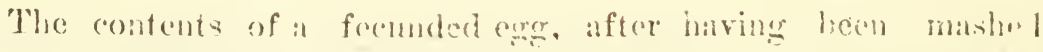
and sprear on a piece of linpid glans will anpear undes a very fowerful mieroserpe eit!er like Freme X. 1, or like ‥

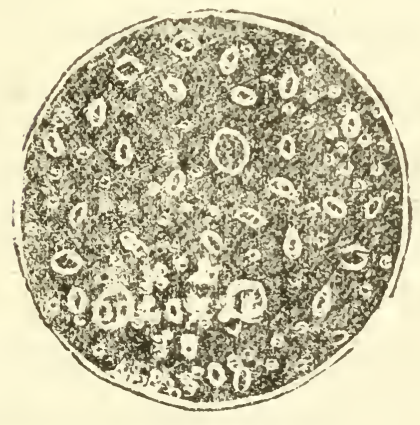

Fig. No. 1.

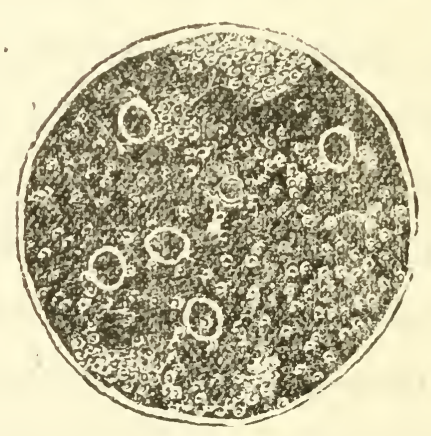

Fig. No. 2.

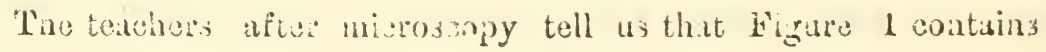


corpuscles [i. o. little hodies or physical atoms] which can be only pereedved

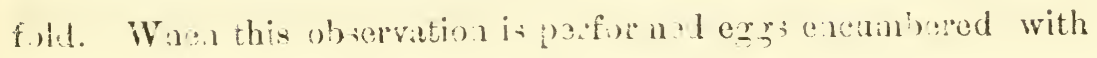
compuseles do not show their protoplatice matter shaped quasi like little dots [as in Figure 2] but among the dotted outlines exhibit a few oroid, or oblong, shapes as in N. i.

Those shades, or shapes, scarcely covering the surface of a sq. 16 th of an in.- - but as bodiless as an umbrage, vibrate [and thence are called ribriones 7 and therefore are prenumed to be inicrocosms, or corpuscles which is all one thing.

But :-Does not vibrate also the substance appearing like little fansparent dots?

It does: sither alive on dead it lose: alive, beatue it is a protoplasm, dead heeane it is in metamomphosis. We will anforee our afirmation with the expressions of Hewisen SPExran;--

* It is not the rastic, nor the artinan, no: the trider, who sees "only something more than a mere matter of course in the hatehing "of a chick: but it is the biologist, who, pu-hing to the nttermost "his analysis of vital phenomena, reaches his greatest perplexity "when a speck of protoplasm under the microsope shows him life "in its simplest form, and makes him feel thas howerer he 


\section{DIS ASES.}

- formulates his piocesses the actual play of forces remains "unimagimable. ${ }^{*}$

And if the dot-like sketeh moves, trembles or viorates, like the oroid one, why the atomism is applied to the riliptic shapes and not also to the spheric ones? Is it perhays beasuse the microscope cammot "describe the organism of the shope which, only, it has discovered?"

What are these parasuitic vibuting atoms, or 'vibunes'? Let us tramsalate the answer:-

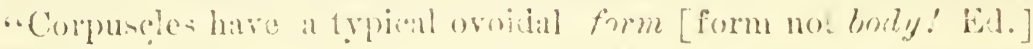
which sometimes becomes rither cylindrial on pylform. 'ilus

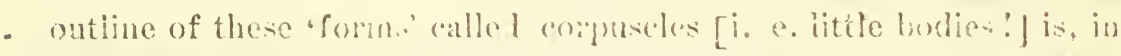
general, a little brown or dark, and at other tincs is scalcely visiob. Their leng:h (we rather say, the ingth of these only vinine foms and not of the eorpuscles) is atmut one eight of an in. and tho

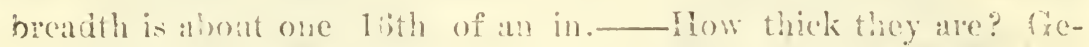

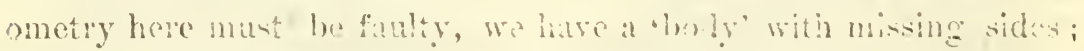

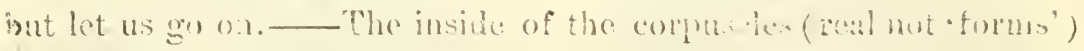

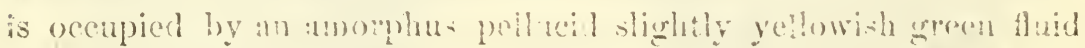

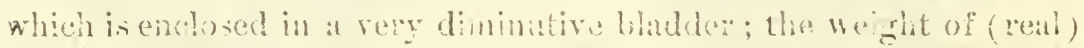
corpuseles is hearior than thr li fuid elenent in which they $\because \mathrm{r}$. To find oat-han!- - what is thoir natare they ware tryed with

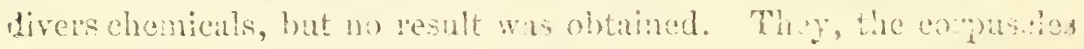


and not the fearful forms, are insolubte cither in hot on in ice wafer: alcohol, ether, potash do not affect then and neitier liquid mineral acids: on the contrary, they are destagerl by condensed mineral acids... - It is rery clear that the above can be applied to "hodies, even intinitesimal, but not to vain unorranized ain bubbles or forms. -

- lebert informs that, real coppuscies malibly hy fissiparus separations (which we admit, oceurs to atoms existing in water), Verson and Habernand say that it happens by seision, and M. Pasteur, dochares it to be ly aramalation (admitad fo: corpuscles living on solid matter ; but what is attributed to the figures seen with a pourerful microscope in the insile of a wee ery, rather belongs to the different genera of atoms existing either in liquid or in solid substances.

So far, then. we have neither a vihrating corpuscle nor a monade [i. e. a moving atom] in the eres, but only a * snoptical appearence artificially procured by means of a compound instrument, and bivefore, any, so called, parassitual have bofalling on the larvat must be proved by dissection and not by an artiacial examination - and 'ouess work' about the egors.

Because, it is eleary acknowleded that, although the eggs might. lo affected as in Fig. No. 1, yet 'sometmes' they will produce a:l healthy brood, whilst tho recommended chosen supiosed unaffocted 
ays, like in Kig. 2, will also 'som times' produce a disensed racs: "Which is which," thoughtfull readers?

\section{II}

Iet us dwell now on the dimeceine point ;--

The appended rig. represents The appended Fig. represcuts ihe gelatinous silk-substance con- the gelatinous silk-substance contained in the hody of healthy lan-tained in the body of discane, i ve [sce 1.9. just hefore they I aluse betore they either spin buile their shrouds. it in a cocoon on die.

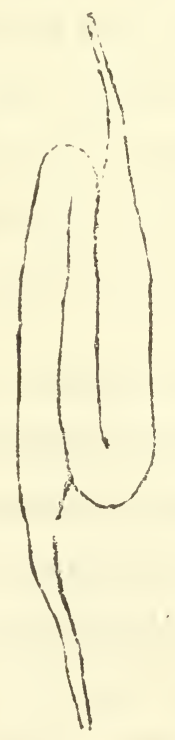

Fig. No. 3.

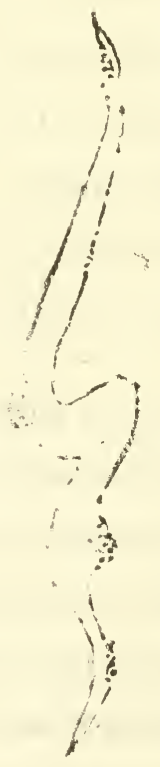

Fig. No. 4.

In the above s'sotches it is easily percoivel that Fig. No. 3 is represented by a clear outline the inside of which is supposed 


\section{I S. IS A S 8.}

to contain the coagulated resinous part of the leaves, is even and turerid throwhout, while the outline of Fig. 4 is irokon many times hy little transparent hladders very mach in shape like the clear ittle figrms seen in Fin. 2 , at l raher thin.

Now wo have lithe bladder; indeed: what ale they? are they romplingles? He will all-wer the question som.

Mantime we call attention to the following:--

We know that from supponed colpusele-infected corgs a good

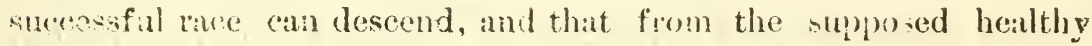

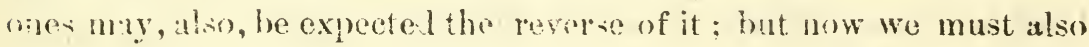
k!nw that larve affected as in Fin. 4 (an, sometimes, live and not ory pas lare silk but also become buttenfles, wn t these butterflies mar be with the littie habhles seen in No. 4 and mal not be so!

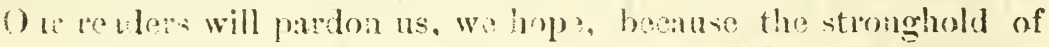
atiomion, on this subject, runs as explained above. But that is not because the pimnacle of the "theory" is revehed, when we hea: fxpoumled again, that the supposed infected butterílies may lay minfected egrss while the heatihy ones can lay them contaminated.

This atomistic principle not grviag the sought for relief to the heart-rending misfortunes caused by the destruction of billions of precious insects, is ton ha:d to be followed, and we look at the effects of the distempers to study positive causes-from which wo may try to learn and paeven'.. . but as yet not [pretend to cure? 


\section{KBRHEXIITIOA.}

All substances apt to putrefy become, whilst they enter into putrefation, a ferment. The entire realm of organic matter when exposed to a quasi heated air in a moist condition, mole or less, rapidily begins to ferment. ** What palses in a state of changu is called a ferment.**

: The fermentation of solid mattrer'is bin appearance? rather simple: e. g. a fruit-rake first undergeres a change of colore, and orber, then hecomes a titting object for Mycology and beconing darker putrefies and dries.

The formentation of liquil subatanees, insteas of, is lather

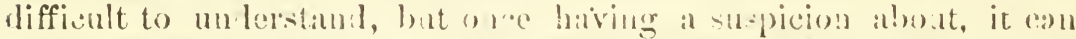

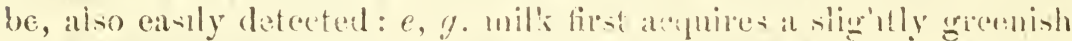
color and has a som tarte [now iactic acid' is preparing the 'for-

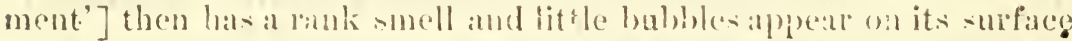
which at this stage is in full fermentation-the habbles being effected ly axpmiton of axyd caused hy the action of the ofor-

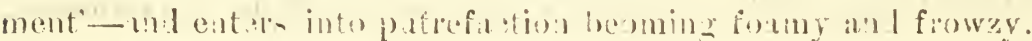

FER.MEVT d wis not enter into abemical composition with the fermenting sub-tances of its polats. 'Acod feanentation' is being subdivided into acetic lactic', 'buatirie acid' and annecini:

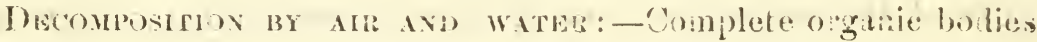
are subject to oxydation and ,utimately. broak no into organic: 


\section{I S E $\triangle$ \& F.}

enpounds carbonic' acid, ammonia and water. If this process' of deromposition takes place siowly, it is called decay: if rapidly in the presense of more water and with the evolution of an offenswe smell, putrefaction: under similar circumstances, when the product is as aseful compound, fermentation.

Iost of the above definitions are axions quoted from standard medical book-, in order to praticaliy common the following diagnosis of the most destructive diseases of "ommercial Larven.

But it must be also explained-previous to come to a closer argument-what is the link existing hetween waterpillars and plants.

Every plant (being inhabited hy neveral -pecies of lanve, that (nnsume its leaves and buds, stems, trunk. roots, sap, and even the old timber) has a capillary system of veins which rontains that organic fluid, or sap. This sap is a chemical compound of liquid substances and atmospheric gases (resin, sugar, water, azote, and oxigen: fand is subject to two poriods of change.

some plants shelter and feed more than one species of insects, but only one syecie in each period preceeding the change.--It has been alrearly explained that "what passes in a state of 'change' is called ferment.-So, - g. the tree-hoppers, crickets, gilded-dandy at. , follow each other by turn in 'sampling' the different tastes tequired in different periods by ein, plum, heery, and apple-trees 


\section{I S S A S S.}

upon which they thive. Now it would be umatural to feed a lion on hay and an ox on flesh ; thence it would be just as much unnatural to 'keep back' the egress of the Silk-Caterpillars in order to hatch them when it is more conrenient to the breeders-i. e. when the leaves are fairly grown-because the insects could not partake of the fresh juice of the plant to which they are naturally destined.

Now Larvae are very volaciom hecause their stomacs are incupable to dissolve their food but merely extract from it a juice: thenre they never drink any water ohtining their necessary moisture fiom the leaves which they eat, no matter how dry they may he. This teaches that, if the Caferpillars ant wet leams they fill themselven with an alulterated juree, and it they eat leaves after the trens have undergone a climacteric, rknnge they devour formented ford. what is still worse, hecause its juice cont:nins the ferment, which enters in their very simple oreatazation and anses them to decazy.

When the trees are in sap they require a constand tontlegratare to allow the juice to circulate in their capillary channels ; somend a ranstorm is fo!lowed by hot sun. we sen the stems of flowers bend down and often without raising up arain___ What is that?_- It is the sction of the rays of the sun on the moist condition of the plants, an action which beats the volatil azote of the learos and caluses the scdden turning of the sal), which means collapse and prompt putrefaction. On the tenderer prorluetions of the vegetable kindon 


\section{I) IS A $\mathrm{S}$ I $\mathrm{s}$.}

the sudden, or climateric taming (which is not the natural change, and often is even fatal to plants) is destructive as above, but struger plikts and trees, alkhough thry will survive the effects of she atmospheric thange, yet they wil! have 'turned' sap which, by degrees. affects their limbs and leaves.

The dimorders of the plants are more explicitly drawn in admin istering their juire to Larve which we know to be alimented by it.

As early as the budding time we may have hatched one or two depustion of Silk-Caterpiliars eros and feed the issued little Larva with the young buds. The insects, being only ahout soc, and partaking of the liquid of leaves comnected with themselves by degrees of heat, guality of moisture, contact with the air, and age, prosper hilse all grubs do in their wild natural state, and grow in the ratio of ansth allawed to vegetation- ind share with it the different govidution of ellorescence which an healthy plant undergoes; but if the efflorescence is turned into delipuescence by bad weather ma fermentation, even the small number of Caterpillars, above quoted, will he subject to it hecalise their vitality, mostly derived from the juice of the flumt upon which they thrive, will be just as unch struck by the "change" as the plants and leaves have been.

Here, perhaps would be useful to state the density af the fluid found in plants before and after turning; but the connections about the leaves having been lengthy enough for the support of the object 
we ean now pass to the topic of this Second part.

Caterpillars breathe hy means of two tabes that extend along the sides of the body and give out to each abdominal segment or ring two branches called spiracles, and these, through the stomata, or breathing holes situated, (and looking like litttle spots surrounded with a slightiy datrer shate) at the side of each ring,

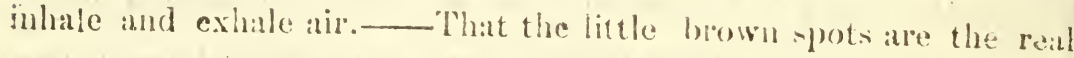
respiratory oreans, is proved by putting oil, ol any greasy sub. stance near these atr-holes, the consequence of which will be i.e mediate death by suffocation. Wrom these trachea alsn pass

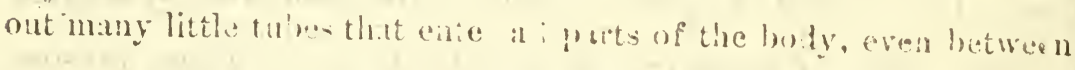
the muscles, and so atrate or rather "oxygenate" the bluod.

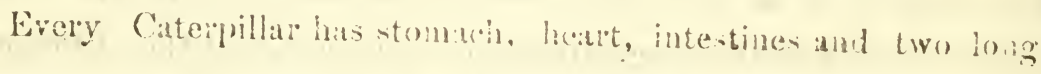
serpentine orgins, like Figure No. 3, which extend to the hind part of the body, and thence back to the neak, whene they opon at the inferior lip. Those tubos contaia, ax already said, the substances

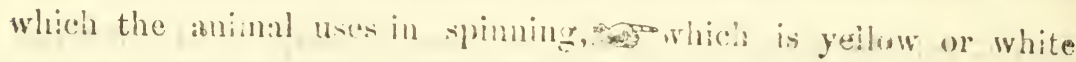

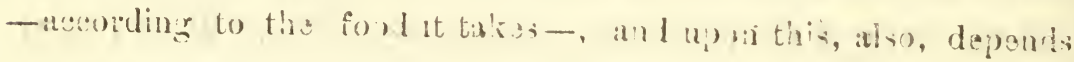
the tineness of the silk thoy make, in the same manter as the quality and color of butter depords upon the food of the cow.

: The juice contatacd in said tubes is nothing more nor les than the juice alkorbed from the leaves and as these contain the liegud 


\section{I 3 เ A S I}

essence of resin, so we find it in the silk-repository-when in froper condition $i$. e. not in a 'forment' - refined in a consistent kind of paste, or varnish, which would be soon ready to pass throng!n the spinneret situated under the lower iip of the insect, to

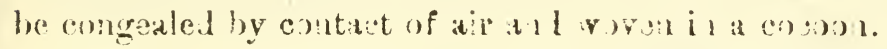

So much explainerl, we wiil make cappital of it to conclude that the existence of commercial larva depends;--

I. From the status of the food from which it is dorived:

II. From climacteric changes which can strike the insects with ferment directly, and not hy the action of the aliment;

III. By unwise or areless 'pearing.'

Here it maty be stated, for the sumport of No. II., that if a Catapillar is pat under water, or alcohol, air bubbles will be seen issuine from innumenable minute holes in all parts of its bodr; and when the stin is taken off from the insect and held up arainst the light, the holes may he distinctly reconnized, and the whole skin; *appears as if it were paforated with an immense number of fine p icis. * Which shows that lapvie live in an ocean of oxygen which; bathes all their external as well as internal organs, and that, when formentation intervenes, it can invade the little creatures not only lyy contaminated food, but also by entering through the 'stomata" and the said large number of pores, which pierce the derma, or skin. 


\section{I I A E E}

From this it must be also established that, the little bubbles seen in Figure four are caused by the expulsion of oxygen from the general system of the inseds-oxyen expelled by intlanmation, or ferment. which turns the blood and the silk-paste in phlegm, or mucus, $i$. r. stite of decily".

It appents that when the rpoinous substance' is contgutated inn silk-valnish by the oramie minciple of the Larre, and not by the atmospheric influence, it is almudant. amber-like, odortes and rather firm: but when it is atrotied hy the affecting influx, we du not see al real silk-varmish, lut only a pale slim, more or less, viscold muck in a decalying state: and we also see that when the weather is unfarotahle the riscid humor pencirates all parts of the Caterpillats' body besides corrupting and diminishing the eongealed silk situated in the serpentine tubes.

Then again: the bore sand exsence has hecome fermented-virus so mudt the more sutden is the liswlution of the infeeted insects. The density of the macus then, (density analyzed fom the vatums

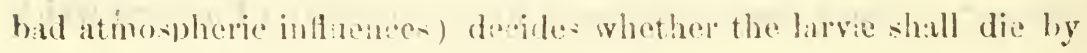
deeary or by putrefation.

$$
\text { [See page } 8: 17
$$

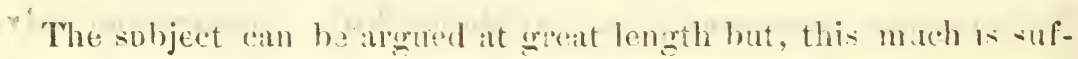
ficient as an esiaty, founded on pathological observations, for cal ing the attention of enlightened breeders. Lat un now specify : 


\section{Distases, in Dotails}

To the present we have evoived this argmment by connectons; now we devolve it ly illustraibons -

The -inemable- diseases at?

Bursting up, Flux o: decay (the

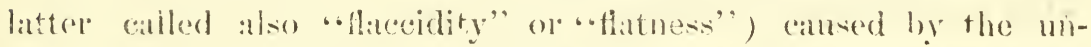
seasonable or tumed foud, and Putrefaction, or Ganglene, anused by direct cimaleterie inlluences:-

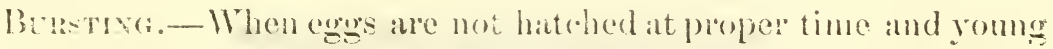

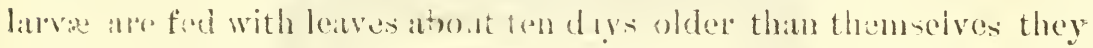

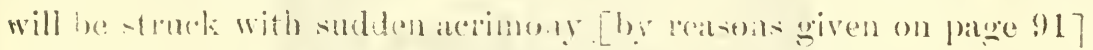
ean in thrir first ance. The Catropillats thus affected at this time, whthont showing any symptom, sadden!y notser at the upper part of

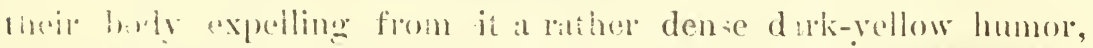
anl in lese than one hour die.

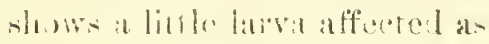

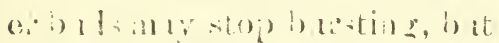
alse, fill prere of the following

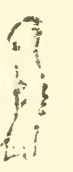
line blark spot on this rout above. Ifoeding with temderon their founth age. they ’ll discasce, becalase the juice of theil foud-phant will, cilher change soon, or be too substantal to be at inmilated hy them.

Erox. or DEar.- If the Caterpillars are fed with turned, or formented leaves, they wial not die suddenly but will linger on untill their noxt moult pouring slime. yelow on white mus from the skin, besides they become thimner and senderer, then end their life in hiack gangrene i. e. putrefilition.

Whis disease strikes the insecte, mostly, near and after the fow th mo:ult. In this case they, either do not shed their skin or, die 


\section{DI \& B A S S S.}

wiriist changrng it. But, at the first stage of their deeay they do not show by any physica! sign the aploronching seourge; yet it mast be always surmised when the caterpillars grosy thin, 'uneven', not showng the shade described for each age and day in this book and positively when they, while youm, rambie about, huddie together mostly on the west end of the shelven and throw themselves, or fill

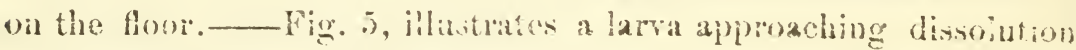
after the 4 th moult :- Body smaller than its a re requires : frouzy gellowish matter from boty and bespatered around: little hornet on hind legs 'flahby and hiake', hotiom of props, or legin, aloo black.

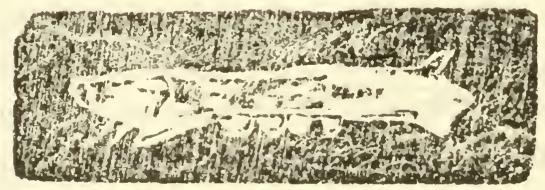

Finure 5.

Gaxgrexe. - Simetimes bibe insechs prosper and look absolutely

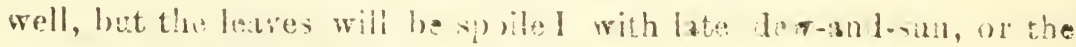
Sout-East wixd bluws, [pure 737 and then ther-at any age, and even while they are settling to weave their shroud-dop lannervel

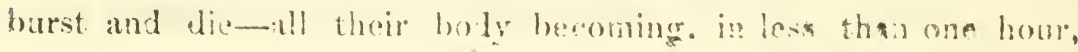
so mueh adranced in putrefactin to derote that it teontents

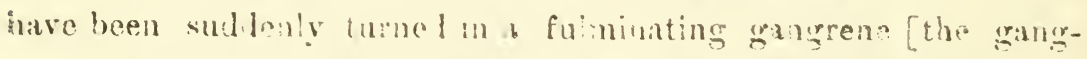
rene enters into infit am ations like the ervipela for spoplexy.

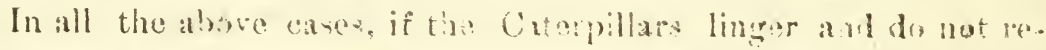

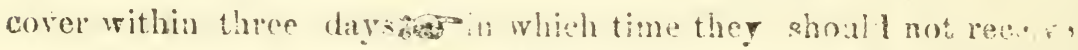
food and he chinged'. cron, iwice a day- hey can ba thrown

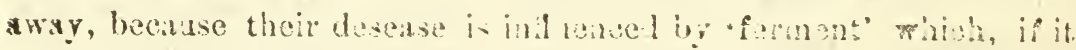


has taken hold of plants and leaves will not cease to rarage the lavie to the last one of them, but if it is by atmospheric disturbances it may disaplear within sueh time.

The above are the more dentructive distempers of the most aseful little beings. Their orgin is clens, and thenefore let us try to avoil, at lext an mach as we and, ali mintakes leading to strike the

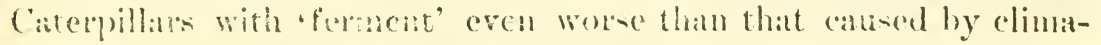

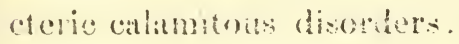

There in no need to dachare, here, that we do not rocognize the

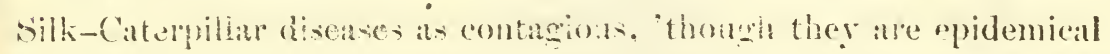
when the juive of their food has heen altered-either by ferment (ri he congahiatom.

The-avoidable- deseates arr:

'Red discase', Atrophy, Vomit.

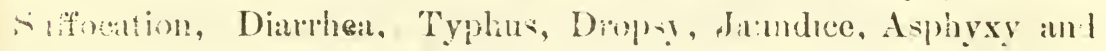
- Conding", these di-olders being aused abo by the primeiple of forment, which in the latter arses has been started hy inproper mo tiatoment :-

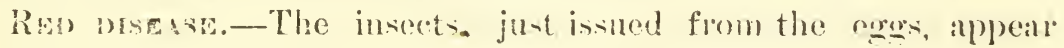
roldish (it has been mule mention on p. 43) if the exg- have been hutehe w wh ton high artificid heat. When not thown awa they fron affected with the tollowing divease and die.

Atromy.-It is choly connected with the incurable' brcar, the o.1y difference between both being that the latier is aused by the

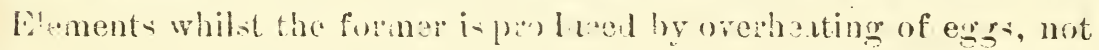
ful enough, too numy leaves at ons time, crowding, uneveness, not enongh of arr, too ank leaves to youg larve, too tender to the older ones, not 'changing' and all other canelessnesses. Caterpillars 
affected with Atrophy Li.e. Wasting of the body-carsed by bad rearing] may recover. sometimes, provided that they are better and neater kept; bat they neither car wrive a good product, nor can be recommended for reproduction. When suffering with this disorder they are not lively, do not moult at giren time. eat less. losk slender and t'erir color is mot pearl-white but rather male-white and seems shaded with dust.

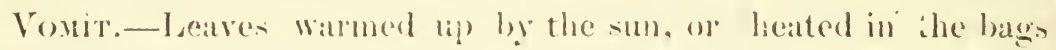
for gathering them, anume vemit. Feeding shruld be stopled at onces, and fumigations of sulphat must he produced in the rom untill the vomit is stopped, thro the animats ane changed and forl

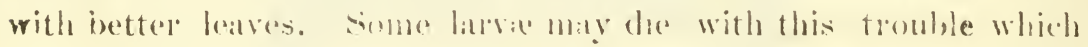
is platuly sean in the weron spots with which the patper is solled, also the body and, especially the, head and mouth of the Caterpitalr.

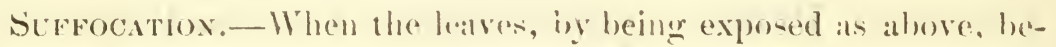
come wifhered and alle eaten hy the humgly insols, also whon tender baklis are given to grown insects ol oid leaves io little ones, they are stratigled in vemiting. The procatutens set down angin-t Vomit shomil he prateticed in this catse.

Drankat.-It is emblatred in the two last complaints and should be treated aceordingly. But when the (aternillats are fed with baves not preserved for a di!y, or so and the sason is a wet one. it is imgrosibibe for them to assinilate the thin juice, and therefore they get alon sick wath this disease: in this catse a little anadultereted' flowe springled on the leares will do good.

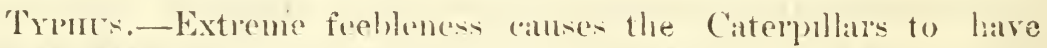
*purple spots* cepecially on the head and around the "obreathing- 


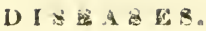

bres. Undoubtedly 'ferment' in the leaves, on the litters and, even. in an unauitable room for coeoonery, becoming virulent, causes the

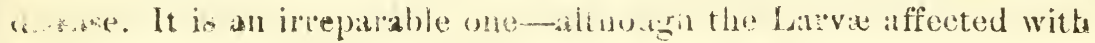
it. sometimen, spin, but, only "lasable" cocoons. Typhas is rathes an exceptonal malady than a geneal one: when they are struck they will be seen dead and diemg as in the fuilowing Figures.

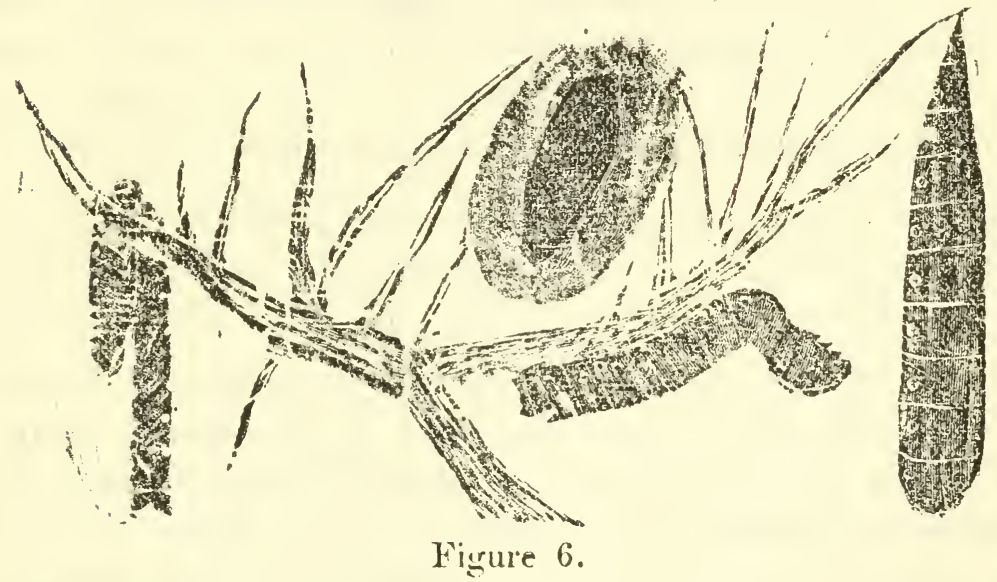

The a';ove shows a dead Caterpillar laying across a twig on the lett; another dead one hanging by its onout on the right: a dieing ore at the underpart of right manch and another dead in the cocin above after having hecome a Crysahs. The cocona is badly * ned black, and in the shims of dead insects is found only a black, f.e ared liquid apt to come fouth at any moment.

When the Caterpillars are doomed thus, it is generally said that hley dis with the black scourge' - which realy denotes the effects and not the cause of the disease or the disease itself. Somctimes 
the body of dead havio does not dissolve, as on previous page, but solidifies: then it is sad that they died by calcination-in Itaiba calcino, in German, Pilasueht, in Fench, Wuscardine; the last two appellations implying that the inseds are suched-by-fungi, o. lilled by 'moss'. This theory prevaled when the theory of tho atoms was up: but ob-erations in another line pointed out that the fungi on moss discovered on the de-tioyed insents were the outeoms and not the canse of putrefaction._- Then, to be short: why should

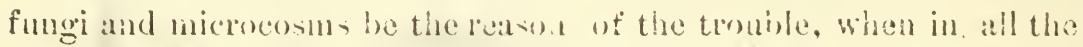
Caterpillar's disorders the intlamation, followed by anderene, is eositively pereeived in more or lest degrees of destructive power?

Dropsy. - When the deaves entain ton much liquid, i. e. when an

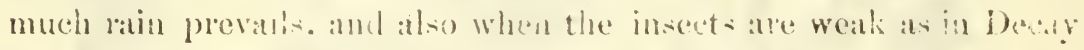

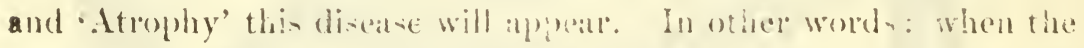

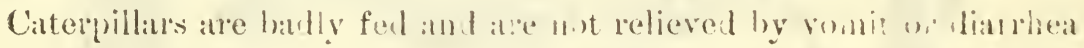

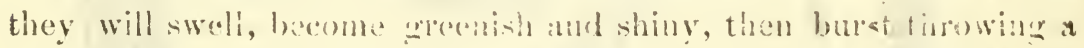
green-yellow liquid and die. This disease is also much akia with

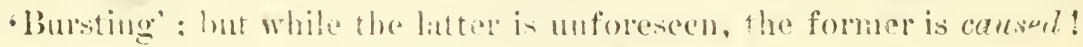
Open air, and remedies given in Vomit, if nsed in time, will heip.

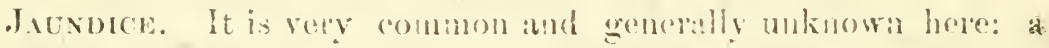
short aneodrote mety show this, better. Mr. "* of * in showilg his knowledge alout the rearing of the "llorms' once satid to the

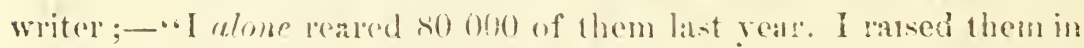
"a gatret without window and fod them somotima once a d.ty :

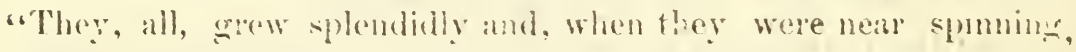
,they were full of silk measuring one inch and three g. around and "nearly four inches in length. They climbed the brush to spin, and 
"either split oyen among the twigs or dropped from them and, pour"ing yellow kater from "rackis in the skin. died". What was th corof of the Caterpillars $\mathrm{Mr}$. * * It was a beatiful yellow color....

L. arve never str dek with laundice in the tirst atges: when so, they are ust iblo those de-cribed hy Mr.*** $i$. e. like the following

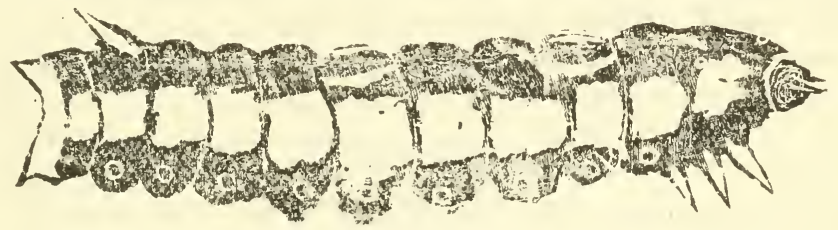

Figure 7 .

What is it? Possily it is the renousus essence altered in a denso viscid subutance instead of to coarnlate in an eiatic one. Keepming

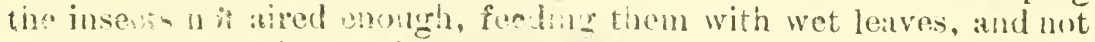
nowing then plenty of space cane- it. As soon as discovered, the Catophars should he inoved in a larererom and be situated a. more sheres. They wll spin a light pridice if they do not die.

Aspryx.-The Lanae struck with asphyxy will appear alive although ihey may have died a couple of hours before. If ant of air, nud sultry weather will do it. By closing windows in the rearingroom a iryal of Asphyxy can be quickly had. [See bottom of p. 73.]

Cormina.-A A very few grown Larve, in every learing, instead of cimbing on the cottages, them pops having beenme scalded-like, (1: sore, on the litters, shrink and curl up like in Fig. 8; then

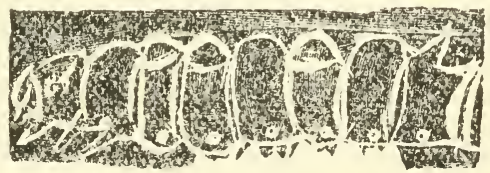

Fingure 8.

luane worthles Chryalides withont weaviar cocoons; but if they are imprisoned in a small box of each in a litile cone made with paper they will spin mediun shrouks. 


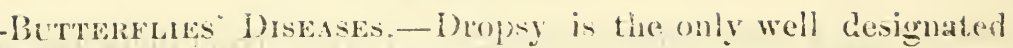
Disedse of the butlerflies, hecau-e. when ill wian it, they plandyly show its indications, which are: deep way color ; hargely swobleia belly; dark wings : almost motionless; oiten unfruitful ete. Inal altholigh this di-eases shows itself without ditienlty, yet it musi bo admitied that huttertlies sometimes are also affected with Typhin. or -hlack-scurese': in this casce, as they had no power to develop inso a eomplete perfect inset, so their wings are short uneren and reph

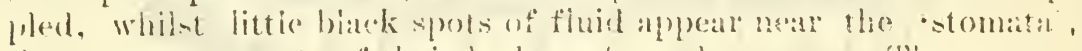
the mpler segments of their hody and on the wages. These spols wore the visal humor, or bhod. of the insects; this humor not having the density posiessed by andity hlowe and theding relapsed

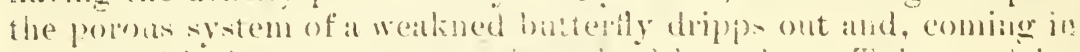

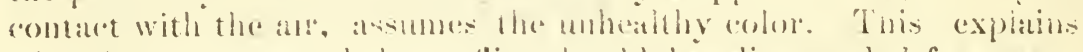

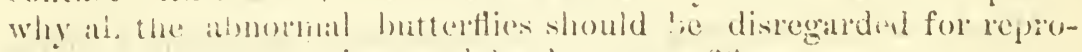

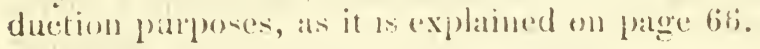

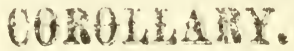

The following inference may be tamb drawn from all the information entatined in this Thealline:-

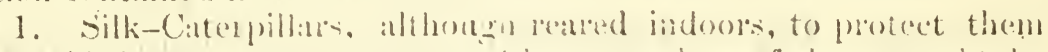

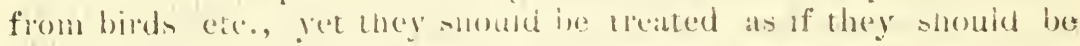
livan in their Naturat statr.

2. Considoring that they anos be neglocted ; that the atten-

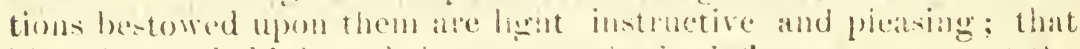
hired lathor is high, and hat atmo-pherice inthence sisty thut the

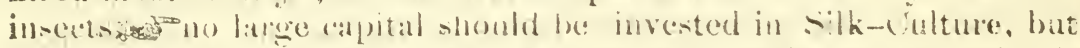

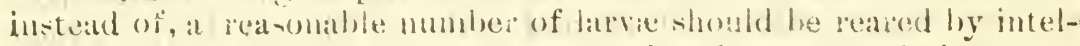
logent perous-who have elime to spated and aterommodations.

3). I fortane cammot be malde in qrowing sik: yet if las mem-

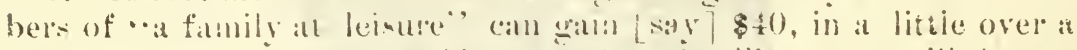

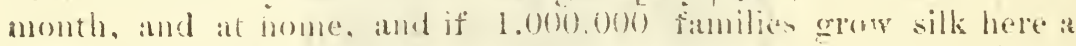

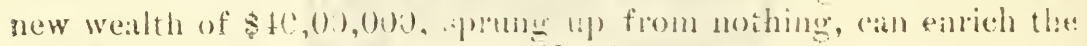
honest and whinge people of the "L.s.

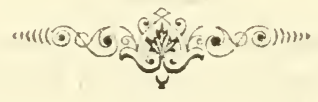




\section{GENERAL TABLES.}

One ounce of eggs of Caterpillars producing yellow cocoons, contains about........40.000 Ja anese breed. contain about....60.000

The produce from each ounce of ex- can be estimated thus;yellow breeds Japanese breeds

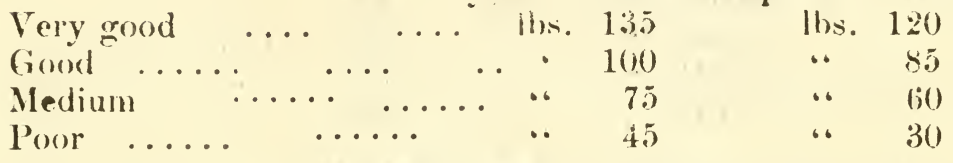

On a produce of

\begin{tabular}{|c|c|c|c|c|c|c|c|}
\hline s. 135 & ". & " & & from & 8.0000 & ts & 6.000 \\
\hline 100 & “ & . & ‘. & . & 5.0000 & . & 8.0100 \\
\hline 75 & .. & .. & .. & .. & 15.000 & . & 18.000 \\
\hline 45 & . & “ & .. & . & 25.000 & . & 27.000 \\
\hline
\end{tabular}

A verager price of frexh yellow cocoous " Japaties " diry ، Caterpillars or egrgs lost or dead are 
The head of a Caterpiliar that has just cast its skin is, at least, four times larger than it was bofore.

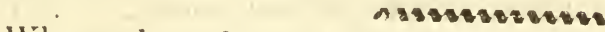

When a born larva is in lengrti 3 sixteenth of in. shoull be

After the first moult

" serond ".

6. third "6

$\therefore$ fourth 6

I: full growth

، 8

6 15

.6 26

“ 42

. $\quad 56$

One ripe Caterpillar weigh from

"6 rorysilis

.

“ femile Butterfly ،

“ male

flom
$\ldots$
$\ldots$
$\cdots$

\section{5}

45

28

15
80

5.5

32

$\therefore 0$
Grains

66

6

66

THE END. 


\section{The Mississippi Vally Sill-oulturg Entorpise WHAT IS IT?}

The ams of the Fim linown as alowe are the followng;-

1. It intends to estahlish heresilk-reeling-mills, and to do so, it is armaing and oreanazing the whote country for mising a rearly silli-erop : imports of repled-sill in 1580 were: $\$ 12,024,4995:$ im-

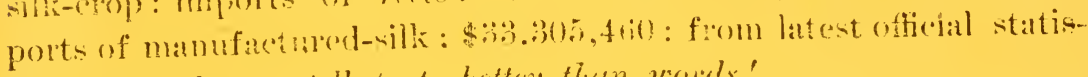

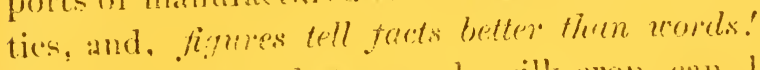

2. Konwing that a yealy silk-erop ran he grown here (as is

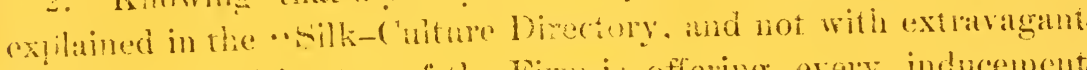
outhys") the Birector of the Firm is offering every inducement to lead into silk-Culture all wiling persons, without wharging them nader :ny pretence whatever!

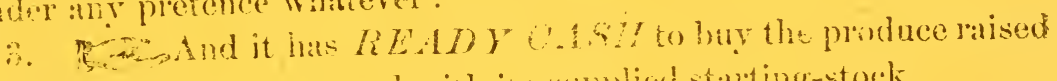
unrer its management, and whi $\mathrm{i}$ splplied stanting-stock.

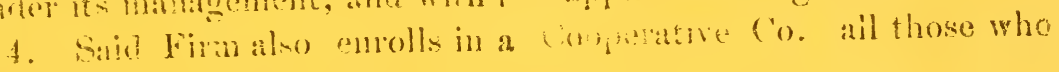
(grow silk, ast abore:

5. Thi ronperators of the Company hering entithed to divilendse withont highng any seck, when the business is fully established;

1. The number of cooperator's, o: members of this co.. to be limitid at wot orer one thousand fö the present and to ba ralimited when the prosshibities of the Co. ane fully developend:

7. So, if this Co. supplies ma-silk rnough within one. two or three years, and this silk is recled at the Company's millk. all its members will be entitied on FlWTY per ent of the NFT protits eamed from the sale of the repiel-silk; the wher fify to gro to the advancement of the sili-manufarturing business and to the cappital employed to start with.

8. The above ruls is also applied if the silk-looms sha!l bo started in due time.

9. The present management of the M. V. S.-C.. C. reserves its rights to camploy, in its bonches, only mombers who are capable to perform some sperial duties, for the ousiness.

10. Agreed that the interest of the M. V. S. C. C., which is 
only a Cooperative Company, an be ony liquidated fol payment. of ll:s own indehiedness (if it will have any) - is members, being copartuers, candate he made responsible.

11. Yet the nembinof the Co, can ask alyeconting of the busmess, if any frum will lo atdranced into it :

1:- So, if the enlnings are abnte the whole expenses-thoso for the adranement of the Enterprise inchder, as buildings ete., and no dividents al'e paid, the "real estate' of the (i). cain be seized and cialinis assesoned thereof.

13. But the hasiness *if not an?enahle under the alove articio

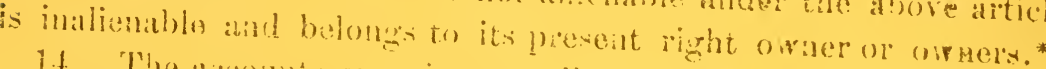

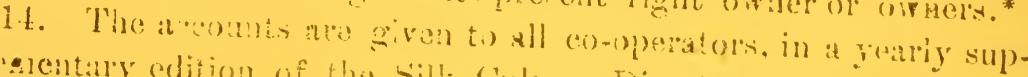
plesentary adition of the silk-Culcire Dorectory.

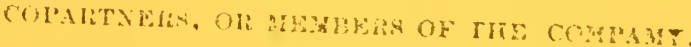

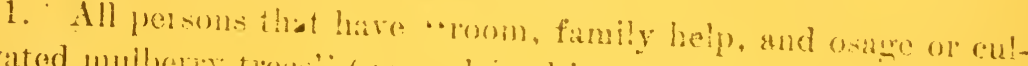

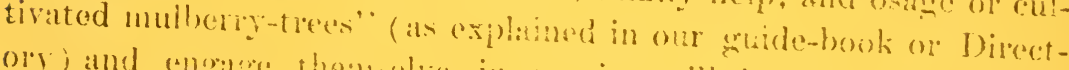

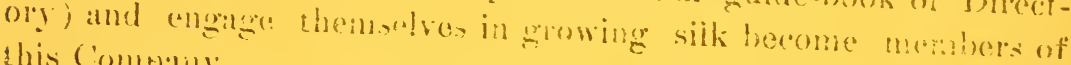
this (ompratily.

2. The members ane whly thowe who subscribe the "arriement

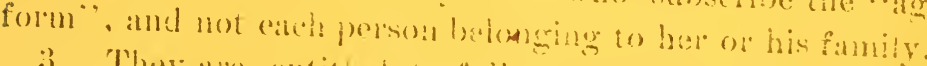

i). They are entitied to fully orte hali of the oumbag of the

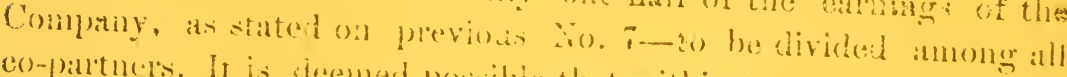

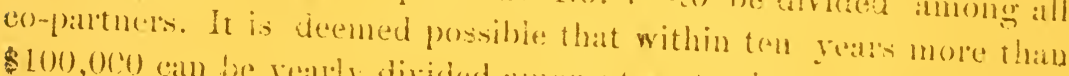

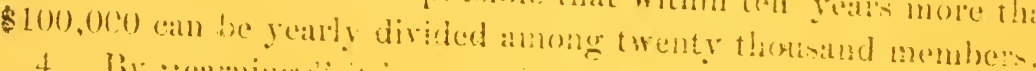

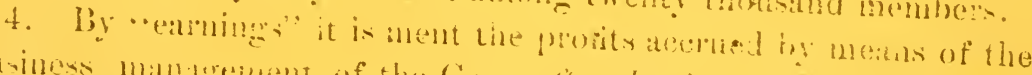

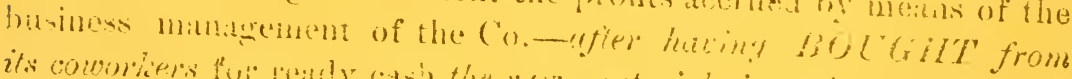

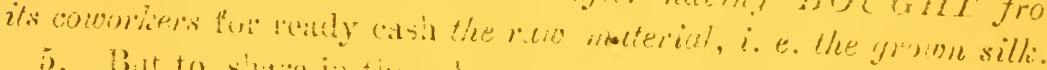

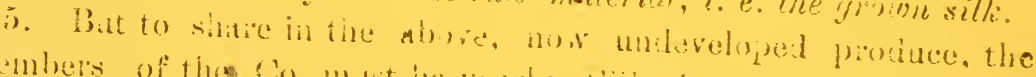

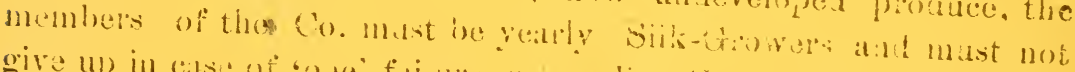

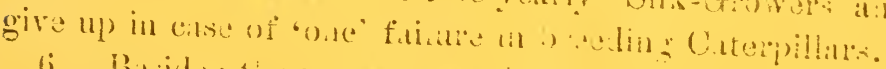

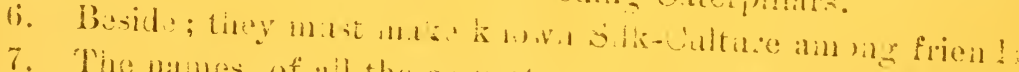

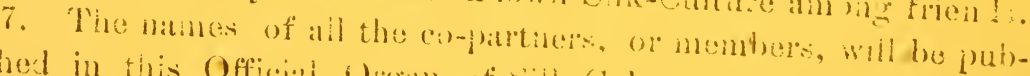

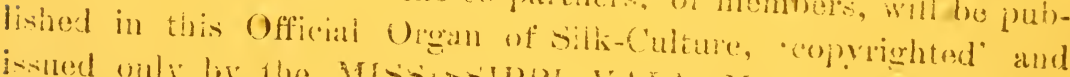

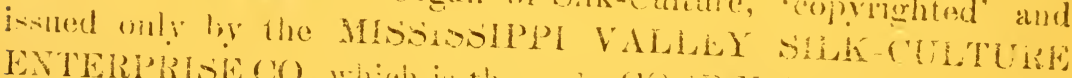

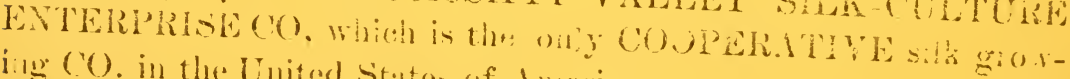
ine (O). in the United Staten of Anerical.

$\therefore$ Rearl the Nullete in this pitper. 



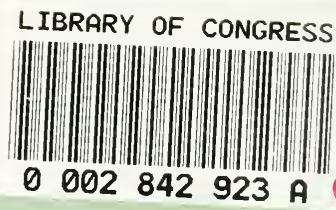

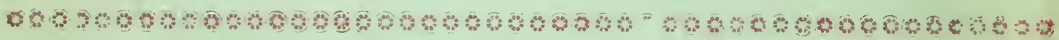

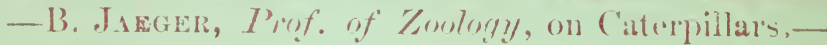

* So ear and amusing is the process of growing silk that, it is supriving that young peonle living in ou country villages do not more often engage in it. Nothing would he easier than to raise silk from the procecds of which eurh individual might realize a hand. some salary. But to say nothing of peruniary advantage, the ennobling nature of the employment ought to be ample compensition for all the care their culture reguires. certuinly a sufticient remmeration for so many ntherwise idle or mis.pent hours.**

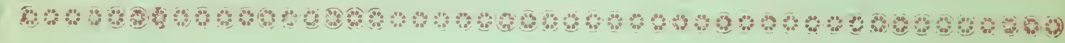




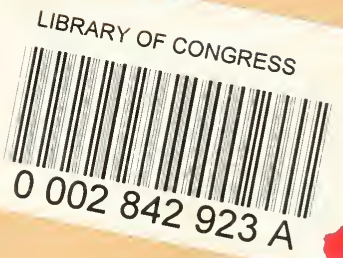

Hollinger Corp. pH 8.5 